Atmos. Chem. Phys. Discuss., 9, 81-134, 2009

www.atmos-chem-phys-discuss.net/9/81/2009/

(C) Author(s) 2009. This work is distributed under

the Creative Commons Attribution 3.0 License.

\title{
Quantitative long-term measurements of VOC concentrations by PTR-MS: annual cycle at a boreal forest site
}

T. M. Ruuskanen ${ }^{1}$, R. Taipale ${ }^{1}$, J. Rinne ${ }^{1}$, M. K. Kajos ${ }^{1}$, H. Hakola ${ }^{2}$, and M. Kulmala ${ }^{1}$

${ }^{1}$ University of Helsinki, Department of Physics, P.O. Box 68, 00014 University of Helsinki, Finland

${ }^{2}$ Finnish Meteorological Institute, P.O. Box 503, 00101 Helsinki, Finland

Received: 19 September 2008 - Accepted: 20 October 2008 - Published: 6 January 2009

Correspondence to: T. M. Ruuskanen (taina.ruuskanen@ @elsinki.fi)

Published by Copernicus Publications on behalf of the European Geosciences Union.

VOC concentrations: annual cycle in boreal forest

T. M. Ruuskanen et al.

Title Page

Abstract

Conclusions

Tables References

Figures

14

4

Back

Full Screen / Esc

Printer-friendly Version

Interactive Discussion 


\section{Abstract}

Atmospheric concentrations of volatile organic compounds (VOCs) vary diurnally, seasonally and annually. Therefore continuous long-term measurements are needed to properly describe the atmospheric levels of these chemically reactive compounds. We 5 conducted on-line measurements of atmospheric volume mixing ratios of several VOCs in the European boreal region with a proton transfer reaction - mass spectrometer (PTR-MS) over a 15 month period. The measurements lasted from spring 2006 to fall 2007 and were conducted at SMEAR II station in south-western Finland. The measured compounds included for example methanol, acetone, sum of isoprene and 2methyl-3-buten-2-ol (MBO), monoterpenes and benzene. The VOC mixing ratios were measured inside and above canopy, during every second or third hour. The PTR-MS was calibrated regularly and background signals of VOCs were measured every second or third hour from the zero air and subtracted from the measured volume mixing ratio. In the continuous measurements at moderate VOC mixing ratios we observed that the PTR-MS has to be calibrated and SEM operation voltage checked regularly, at least twice a month to ensure reliable measurements. Of the measured VOCs, methanol and acetone were the most abundant ones, their volume mixing ratio medians were in the order of $1 \mathrm{ppbv}$. Volume mixing ratios of methanol, acetone, isoprene-MBO and monoterpenes were high during summer and low in winter indicating mostly biogenic or photochemical local or regional origin. Benzene behaved in the opposite way, while seasonal variation of acetaldehyde and methacrolein-methylvinylketone (MACR-MVK) was less profound. Methanol, acetone, isoprene and monoterpene volume mixing ratios had clear diurnal patterns during summers, while the mixing ratios of other VOCs did not exhibit this behavior. During winter we did not observe systematic diurnal cycles in the VOC volume mixing ratios.

9, 81-134, 2009

VOC concentrations: annual cycle in boreal forest

T. M. Ruuskanen et al.

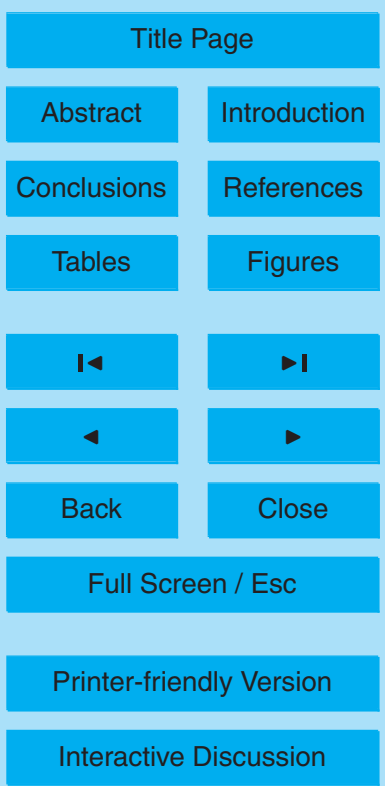




\section{Introduction}

Volatile organic compounds (VOCs) are a large group of compounds with atmospheric lifetimes from seconds to months (Atkinson and Arey, 2003). On a global scale VOC emissions are dominated by biogenic sources (e.g. Guenther et al., 1995; Simpson 5 et al., 1999; Lindfors et al., 2000). However, in urban areas primary and secondary anthropogenic sources dominate (e.g. Piccot et al., 1992; Hellén et al., 2006). Once VOCs have entered the atmosphere they play an important role in atmospheric chemistry as they are oxidized by hydroxyl radicals $(\mathrm{OH})$, ozone $\left(\mathrm{O}_{3}\right)$ and nitrate radicals $\left(\mathrm{NO}_{3}\right)$ (e.g. Atkinson and Arey, 2003). VOCs can also deposit on wet or dry surfaces 10 and thus be removed from the atmosphere. If the oxygenated VOCs remain in the atmosphere they are oxidized further until ultimately carbon dioxide $\left(\mathrm{CO}_{2}\right)$ is formed. Ozone formation and destruction (Atkinson and Arey, 2003) and aerosol particle formation and growth (Kulmala et al., 2004; Kourtchev et al., 2005; Tunved et al., 2006; Kroll and Seinfeld, 2008) can take place during VOC oxidation thus affecting air quality 15 and climate.

Traditional VOC measurement methods with sample collection on adsorbents and subsequent chromatographic analysis are time and labour consuming. The sampling requires ozone removal that can also remove the compounds of interest and the analytical methods are often unsuitable for determining oxygenated VOCs. These problems are overcome in proton transfer reaction - mass spectrometry (PTR-MS) which is an online method suitable for continuous measurements of VOCs at ambient concentration levels (Lindinger et al., 1998; de Gouw et al., 2003; Warneke et al., 2003). With PTR-MS ambient air is continuously pumped into the instrument where VOCs with proton affinity higher than that of water are ionized in proton transfer reactions. Several 25 VOCs can be measured consecutively with time resolution of $0.1-10 \mathrm{~s}$. Most VOCs are considered not to fragment and can be measured at their molecular mass plus one. The disadvantage of PTR-MS analysis is that compounds with the same mass cannot be separated and identification of the compounds has to be confirmed using other

9, 81-134, 2009

VOC concentrations: annual cycle in boreal forest

T. M. Ruuskanen et al.

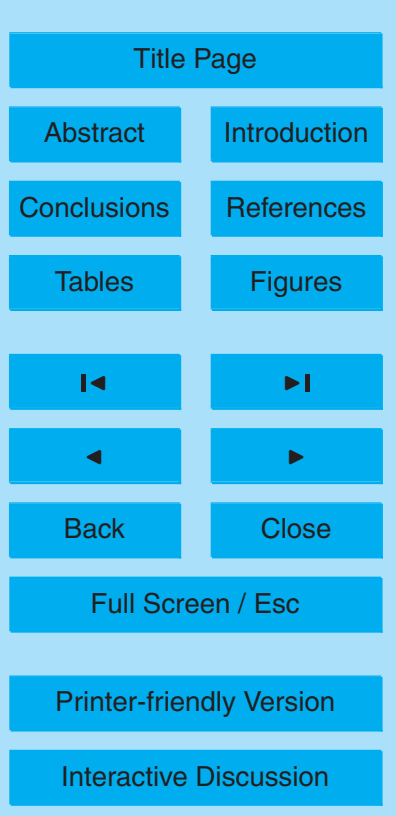


techniques.

PTR-MS technique is used in an expanding number of VOC measurements (for a review, see de Gouw and Warneke, 2007). PTR-MS has been used for ambient VOC mixing ratio measurements in numerous campaigns lasting from days or weeks 5 to several months (e.g. Ammann et al., 2004; Crutzen et al., 2000; Holzinger et al., 2001; Warneke et al., 2002; de Gouw et al., 2003, 2004, 2006; Salisbury et al., 2003; Karl et al., 2001, 2002, 2003). However, only a few continuous measurements lasting a year or longer have been reported (Holzinger et al., 2006; Schnitzhofer et al., 2008). Taipale et al. (2008) presented our procedures for long-term stand-alone field mea-

10 surements. These automated VOC measurements, systematic calibration and explicit volume mixing ratio calculation procedures enable consistent quantitative long-term measurements. In this paper we will present over a year of continuous VOC volume mixing ratio measurements. Continuous measurements over all seasons with temporal resolution that can catch diurnal variation are needed when VOC concentrations need to be described correctly. Especially biogenic emissions go through seasonal changes from low, if any, emissions during dormant winter to high activity, and emissions, during growing season. Seasonality of removal processes is connected to e.g. solar radiation. Solar radiation is low during short winter days on the contrary to light midsummer days, this as well as other meteorological conditions affect ozone and $\mathrm{OH}$ radical concentrations as well as photodissociation processes. These seasonal and diurnal patterns of sources, sinks and transportation affect the ambient mixing ratios of VOCs: terpenoids with short lifetimes are dominated by local biogenic emissions, methanol and acetone with intermediate lifetimes are affected by various local and regional sources, while anthropogenic benzene is a long lived VOC that can be dominated by long range transport. Identifying and verifying the key processes and their impact on the ambient concentrations of the different VOCs require measurements that are continuous around the clock and throughout the year.

VOC concentrations: annual cycle in boreal forest

T. M. Ruuskanen et al.

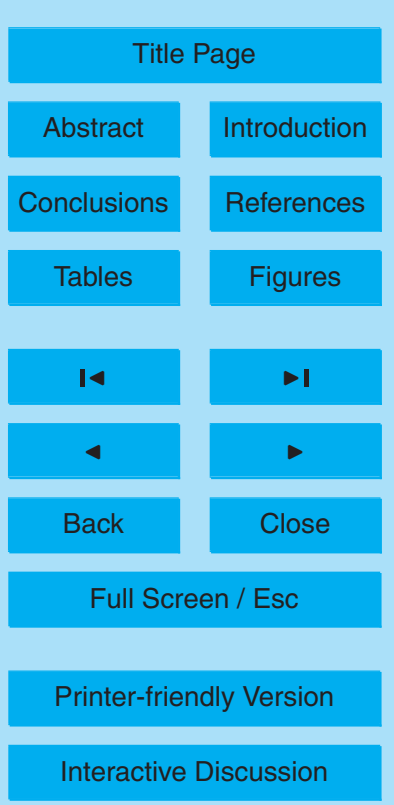




\section{Experimental}

Taipale et al. (2008) present the measurement set-up, calibration procedure and mixing ratio calculations in detail and we will present here only differences to the procedures. All data is presented in local winter time, UTC $+2 \mathrm{~h}$.

$5 \quad 2.1$ Measurement site

The measurements were carried out at the SMEAR II measurement station (Station for Measuring Forest Ecosystem-Atmosphere Relations (Hari and Kulmala, 2005)) in Hyytiälä, southern Finland $\left(61^{\circ} 51^{\prime} \mathrm{N}, 24^{\circ} 17^{\prime} \mathrm{E}, 180 \mathrm{~m}\right.$ a.s.I.) in 2006 and 2007 . The forest around the station is dominated by Scots pine (Pinus sylvestris) sawn in 1962 10 with some Norway spruce (Picea abies), aspen (Populus tremula) and birch (Betula). The canopy height at the measurement tower was about $16 \mathrm{~m}$. The $40 \times 40 \mathrm{~km}^{2}$ area surrounding SMEAR II station is mostly covered by forest $(71 \%)$, the rest being lakes and rivers (13\%) and agriculture (10\%) and other minor land use types (Table 1). This nearby land cover represents the average of land use in southern Finland (Tulokas, 2005).

\subsection{Measurement set-up}

VOCs were measured from a scaffolding tower between 12 June 2006 and 24 September 2007 with a proton transfer reaction - mass spectrometer (PTR-MS, Ionicon Analytik $\mathrm{GmbH}$ ). Measurements were conducted from 4, 14 and $22 \mathrm{~m}$ heights during the whole time. In addition the volume mixing ratios from 7 and $10 \mathrm{~m}$ heights were measured until October 2006. In this paper we concentrate on measurements from 14 meter height inside the canopy. The Teflon sampling tubes with $8 \mathrm{~mm}$ i.d. were $30 \mathrm{~m}$ each and maintained with a constant sample flow of $15 \mathrm{I} \mathrm{min}^{-1}$ before October 2006 and of $17.5 \mathrm{I} \mathrm{min}^{-1}$ from then in each tube. The tubes were heated since November 2006 . Initially ambient air volume mixing ratios from each measurement height

9, 81-134, 2009

VOC concentrations: annual cycle in boreal forest

T. M. Ruuskanen et al.

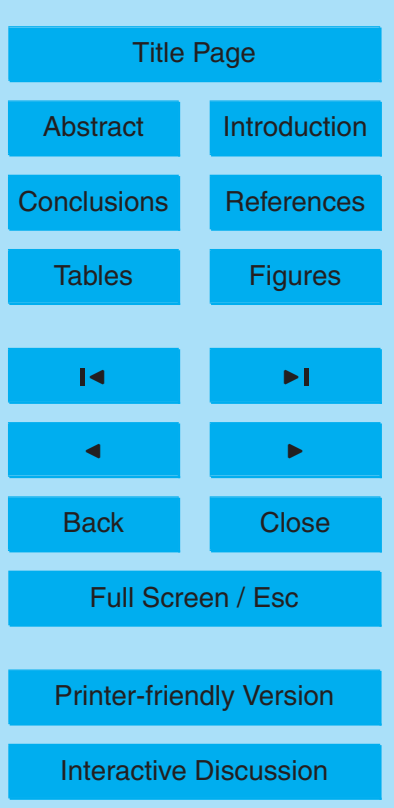

Interactive Discussion 
were measured consecutively during every second hour, with disjunct eddy covariance flux measurements every other hour (Rinne et al., 2007). Timing of measurements changed in March 2007 when a chamber with a Scots pine shoot was added into the measurement cycle. Thereafter ambient volume mixing ratios were measured every 5 third hour.

\subsection{Calibration of VOC volume mixing ratios}

The PTR-MS was calibrated weekly or every second week as presented by Taipale et al. (2008) using a VOC calibration gas standard (Apel-Riemer Environmental Inc.) that contained compounds associated with measured masses (Table 2). The calibration gas standard was diluted using VOC free air that was obtained from ambient air with a zero air generator. Zero air generator (Parker ChromGas) model 1001 with a flow of $1 / \mathrm{min}^{-1}$ was used until November 2006 and model 3501 with $3.51 \mathrm{~min}^{-1}$ flow or less after that. The background signals of VOCs was measured every second or third hour from the zero air, in the same way as in the volume mixing ratio measurement. The efficiencies of used zero air generators were measured in laboratory (data not shown here), and they removed effectively compounds used in calibrations, except for the model 1001 generator which was unable to produce zero air for toluene (not presented here). Prior the calibration the Secondary Electron Multiplier (SEM) detector voltage was checked and adjusted if raising the detector voltage by $100 \mathrm{~V}$ resulted in more than a $20 \%$ change in M21 signal.

\subsection{Calculation of VOC volume mixing ratio}

The volume mixing ratios were calculated, as presented by Taipale et al. (2008), using sensitivities determined from calibrations. Measured primary ion and water cluster ion signals were used to normalize the VOC signals, except for benzene, which was normalized with the primary ion signal only, since benzene has been reported not to protonate by the water clusters (e.g. Warneke et al, 2001a; de Gouw et al., 2003). The

VOC concentrations: annual cycle in boreal forest

T. M. Ruuskanen et al.

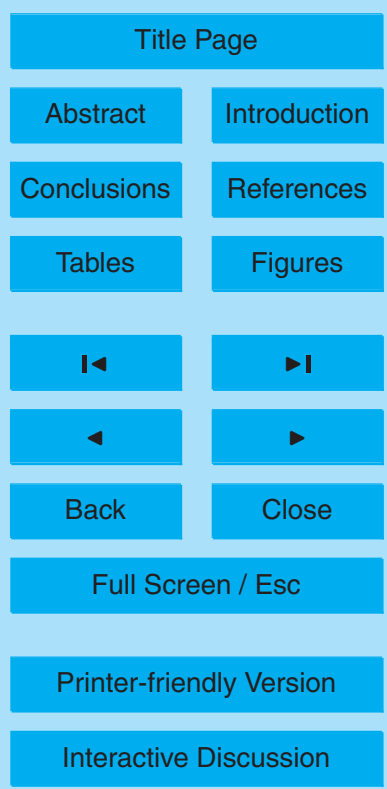


closest measured hourly background signal was subtracted from each measurement. The raw data was inspected for peaks in burning markers (acetonitrile and benzene), however, no indications for local anthropogenic contamination were found. Outliers were removed from raw VOC volume mixing ratio data. For the lower removal limit we 5 used minus half of average of the atmospheric volume mixing ratio during the whole measurement period separately for each compound in question. An upper removal limit of 20 times average was used for monoterpenes and 8 times average for all other VOCs. Filtering the VOC volume mixing ratio data with these limits lead to discarding of $0-0.8 \%$ of data depending on the compound in question. The filtered volume mixing 10 ratio data was used to calculate one hour averages that were used in all presented analysis.

\section{Stability of PTR-MS}

The stability of a PTR-MS was studied in two ways during the long measurement period, first by comparing normalized sensitivities from the weekly direct gas calibrations and second by looking for sudden changes in the measurement signal.

\subsection{Stability of normalized sensitivity}

Changes in sensitivity of the PTR-MS instrument may be sudden, e.g. related to change of the applied SEM voltage, or slow trends, e.g. from the use of too low voltage of an aging SEM. On the whole, the normalized sensitivities of various calibration compounds increased and decreased simultaneously. However, it is important to calibrate using various compounds, as some opposite tendencies in normalized sensitivity are seen for light and heavier compounds (i.e. methanol and monoterpenes) in Fig. 1. The normalized sensitivity varied between $13.07-19.81 \mathrm{ncpsppbv}^{-1}$ for methanol and between $3.68-8.23 \mathrm{ncps} \mathrm{ppbv}^{-1}$ for monoterpenes during the measurement period.

The VOCs are detected as hits of protonated VOCs on the first stage of a SEM and

9, 81-134, 2009

VOC concentrations: annual cycle in boreal forest

T. M. Ruuskanen et al.

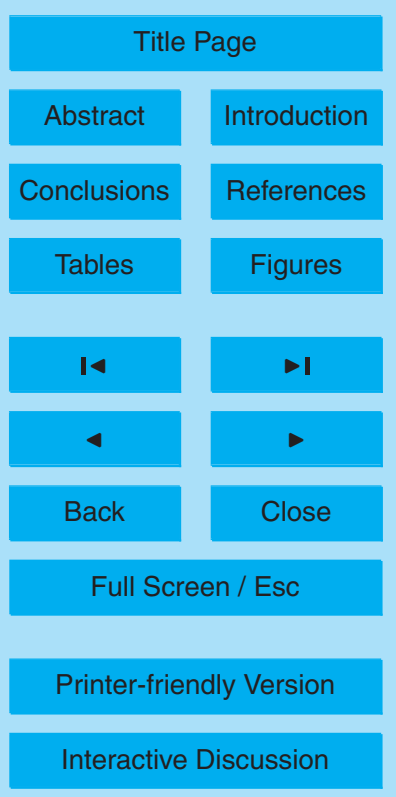

Interactive Discussion 
in principle every hit is measured. However, every molecule that hits the SEM covers the surface and reduces its sensitivity. Sensitivity of the measurements for volume mixing ratios is weakened as the SEM detector ages. First only the signal of heavier compounds is weakened while light compounds are still measured accurately. Raising 5 the SEM operation voltage restores the sensitivity, up to the maximum working voltage. We replaced our SEM about 3 times per year. However, depending on measuring time and measured volume mixing ratios, i.e. on the rate of matter covering a SEM, as well as the used voltage, a SEM can last from few months up to a year. We observed that in our moderate ambient air concentrations the SEM operation voltage needs to be o checked twice a month.

The fluctuation of normalized sensitivity was in the same order of magnitude during periods of constant SEM operation voltages as well as when the SEM operation voltage was raised in between calibrations. We did not observe systematic changes in normalized sensitivity. The aging of a SEM was not observed to result in poorer normalized sensitivity as long as the operation voltage was raised often enough.

\subsection{Stability of measurement signal}

To observe stability of the instrument we studied consecutive calibrations when neither the SEM operation voltage nor other parameters in instrument set-up were changed. The sensitivities of the calibrations altered (Fig. 1), but did not produce systematic 20 changes in the measurement signal of ambient volume mixing ratios (Fig. 2). For example in March-April 2007 the methanol volume mixing ratio level rose before a calibration on 27 March and dropped before the next calibration on 3 April. During the periods of constant SEM operation voltage we did not observe lowering of the measurement signal as the SEM aged. Random changes, however, were observed in the 25 sensitivity. Biggest difference between the lowest and the highest normalized sensitivity during one period was $27 \%$ for methanol. However, most of the changes in sensitivities were relatively small during these periods.

$9,81-134,2009$

VOC concentrations: annual cycle in boreal forest

T. M. Ruuskanen et al.

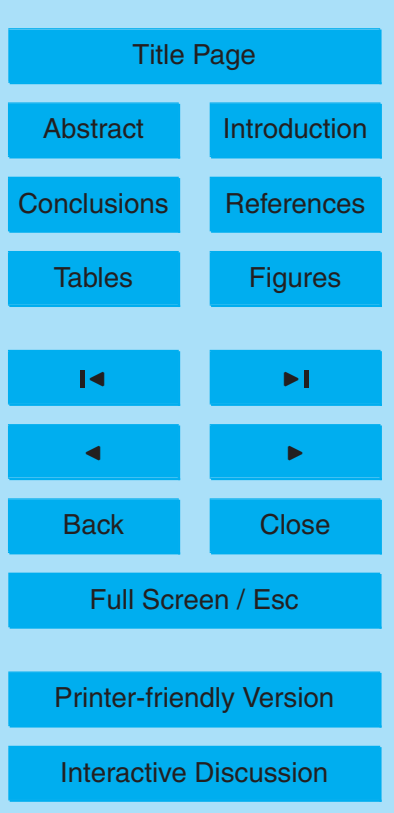

Interactive Discussion 


\section{Volume mixing ratios of VOC}

Medians were calculated from hourly average volume mixing ratios to represent typical volume mixing ratios of VOCs contributing to measured masses or more precisely contributing to mass/charge ratios (Table 2). Monoterpene volume mixing ratios were 5 determined from M137 measurements. We associate M69 mass/charge ratio with isoprene and fragmented 2-methyl-3-buten-2-ol (MBO) (de Gouw and Warneke, 2007) during growing season when both compounds have local and regional biogenic emissions (Hakola et al., 1998, 2006; Haapanala et al., 2006; Janson and de Serves, 2001). However, during winter the M69 volume mixing ratios may be dominated by multiple anthropogenic VOCs that have been observed, but not identified, in urban air (de Gouw and Warneke, 2007). For simplicity we will refer to the measured M69 as isoprene-MBO. The seasons were divided into periods of equal length: winter is December-February, spring is March-May, summer is June-August, and fall is September-November. Unfortunately, we could not determine typical volume mixing 15 ratios for fall, due to instrument breakdowns from October to the beginning of December in 2006.

\subsection{Seasonal variations}

Seasonality of solar radiation governs the meteorology of the site. The summers are flooded with light and nights are short, average global radiation at midday 11:00-14:00, 20 was around $700 \mathrm{~W} \mathrm{~m}^{-2}$ on a cloudless day (Fig. 3). In summer the solar radiation affects the air temperature which typically rose to $20-25^{\circ} \mathrm{C}$ during day, and was around $10^{\circ} \mathrm{C}$ at night. This was also reflected on relative humidity that varied between maxima near $100 \%$ before sunrise when dew was formed and low day-time values around $30 \%$. The winters were the opposite, days were dark and the sun shone only for few hours 25 at a low solar angle, the midday solar radiation was below $60 \mathrm{~W} \mathrm{~m}^{-2}$. The temperature in winter 2006 was below $5^{\circ} \mathrm{C}$, and the coldest period was February with temperatures ranging between 0 and $-30^{\circ} \mathrm{C}$.

9, 81-134, 2009

VOC concentrations: annual cycle in boreal forest

T. M. Ruuskanen et al.

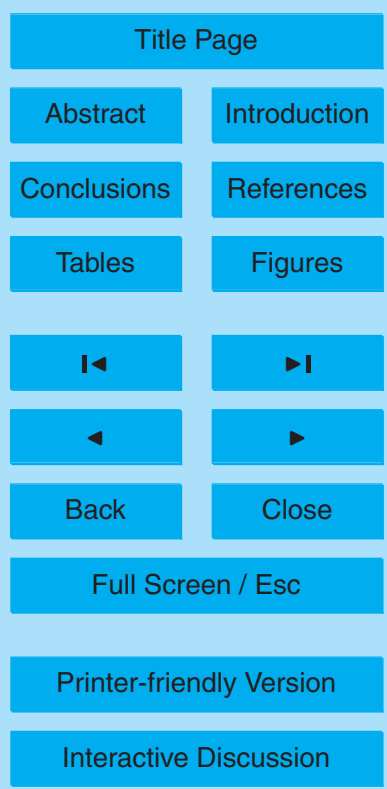

Interactive Discussion 
The measured hourly averages of VOC volume mixing ratios and their daily medians are presented in Figs. 4-8. The typical seasonal values of the VOC volume mixing ratios are summarized in Table 3 for the summers 2006 and 2007 as well as for the winter and spring 2006. More details of the VOC volume mixing ratios as monthly 5 averages, medians, and 5 and 95 percentiles are listed in Appendix A.

The methanol volume mixing ratio median over the whole period was $1 \mathrm{ppbv}$ (Table 3 , Fig. 4), which is similar to the values measured with gas chromatography in remote areas (de Gouw et al., 2003). The seasonal variation of the methanol volume mixing ratio was large. The lowest methanol volume mixing ratios were measured in Decem10 ber, when the median was 0.24 ppbv. This is in the same order of magnitude as Arctic winter methanol mixing ratios: Heikes et al. (2002) reported in a review article median value of $0.250 \mathrm{ppbv}$ for the Arctic; Boudries et al. (2002) reported even lower values of $0.20 \mathrm{ppbv}$ in the remote Arctic. In the spring the methanol volume mixing ratios started rising, and the median was $0.35 \mathrm{ppbv}$. Similar values have been measured previously

at the same site (Sellegri et al., 2005), however, mixing ratios in the remote Arctic are lower (Boudries et al., 2002). The highest values were observed in June, median 4.05 ppbv in 2006 and median 3.62 ppbv in 2007. In summer 2004 Rinne et al. (2005) measured similar methanol mixing ratios at the same site. Heikes et al. (2002) give much lower values between 0.4 and $1.2 \mathrm{ppbv}$ for typical Arctic summer time in a re-

paper, suggesting that the summer mixing ratios at our boreal measurement site are not mere background but dominated by local and regional sources. One source is the surrounding vegetation that emits methanol (Rinne et al., 2007). In the winter, the methanol volume mixing ratio was as low as in the remote Arctic areas and most likely originated from long range transport. From the beginning of spring to the end of summer the methanol mixing ratio was dominated by local and regional emissions.

The acetone volume mixing ratio median for the whole period was $0.9 \mathrm{ppbv}$ (Table 3, Fig. 5) similar to previous gas chromatograph measurements in remote locations (Singh et al., 1994). The acetone volume mixing ratio was lowest in January, when the median was $0.31 \mathrm{ppbv}$. This is slightly higher than in the remote Arctic, where the

\section{ACPD}

9, 81-134, 2009

VOC concentrations: annual cycle in boreal forest

T. M. Ruuskanen et al.

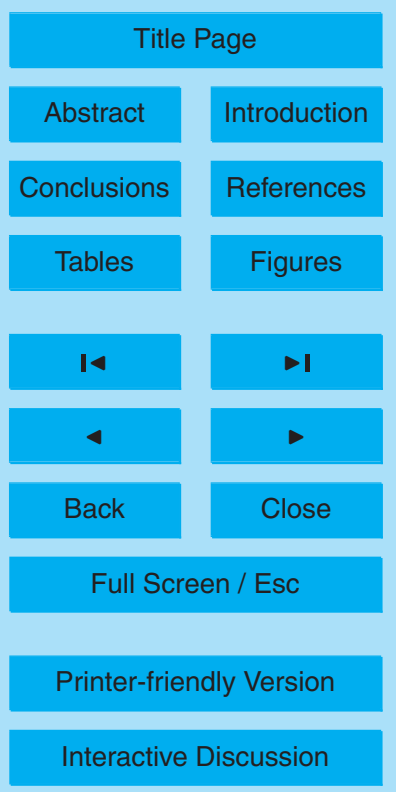


typical winter mixing ratio is $0.20 \mathrm{ppbv}$ (Boudries et al., 2002). The spring was well represented by the median acetone mixing ratio of $0.62 \mathrm{ppbv}$ in March. Previously in March 2003 at the same site Sellegri et al. (2005) measured about three times higher acetone mixing ratios with a chemical ion mass spectrometer (CIMS). However, si5 multaneous measurements with DNPH-cartridges and LC-MS analysis by Hellén et al. (2004) showed mixing ratios close to the results in this study. The acetone volume mixing ratios were highest in early and late summer: in August 2006 the acetone median was $2.44 \mathrm{ppbv}$, and $1.66 \mathrm{ppbv}$ in June 2007. Globally the largest source of acetone is oxidation of VOCs, however, local concentrations can be dominated by pri10 mary biogenic emissions (Singh et al., 1994, 2000). Boudries et al. (2002) observed $1.2 \mathrm{ppbv}$ mixing ratios of acetone in May in a remote Arctic site and they suggested that the most important source was photochemistry, not biogenic emissions. However, our site is surrounded by Scots pine and Norwegian spruce that emit acetone in a temperature dependent way similar to monoterpenes (Janson and de Serves, 2001; Rinne et al., 2007). Therefore, it is likely that a significant contribution is from primary biogenic emissions. The behavior of acetone and methanol volume mixing ratios were similar during all seasons (Fig. 6), indicating that they are controlled by similar source and sink processes.

The isoprene-MBO volume mixing ratio had a clear seasonality with high values during the summers and low during November-April (Table 3, Fig. 7). In the summers, the isoprene-MBO volume mixing ratio median was $0.17 \mathrm{ppbv}$ in 2006 and $0.14 \mathrm{ppbv}$ in 2007. During the growing season, the MBO is emitted by Scots pine (Hakola et. al., 2006) and thus it has local biogenic emissions. At the same time of the year, isoprene has several sources for regional emissions: from Norway spruce (Janson and de Serves, 2001), willow and aspen (Hakola et al., 1998) in surrounding forests and from some of the ground vegetation (Hakola et al., 1998) as well as from vegetation in nearby open wetlands (Haapanala et al., 2006). The winter and spring volume mixing ratio median of compounds corresponding mass M69 was 0.05 ppbv. This is much higher than the winter and spring isoprene concentrations measured at the same site

VOC concentrations: annual cycle in boreal forest

T. M. Ruuskanen et al.

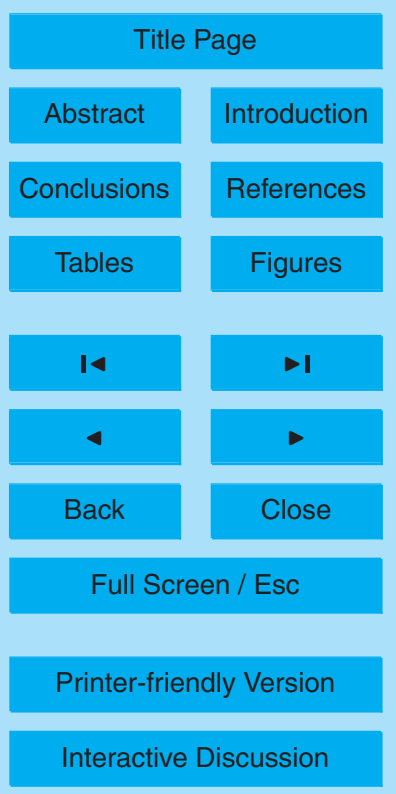


from adsorbent samples with GC-MS technique by Hakola et al. (2003). The isoprene mixing ratio has a clear maximum during the growing season from mid-June to midSeptember (Hakola et al., 2000; Hakola et al., 2003), since isoprene is mainly emitted from mature leaves. The isoprene emissions cease when the leaves are shed and also 5 the MBO emissions from Scots pine end in the fall (Tarvainen et al., 2005). Thus it is probable that during winter and spring M69 is dominated by some other, perhaps anthropogenically emitted, compounds (de Gouw and Warneke, 2007). Sellegri et al. (2005) also measured the mixing ratio of the sum of isoprene and an unknown compound to be $0.09-0.19 \mathrm{ppb}$ in springtime using a water-based CIMS, giving similar 10 results to this study.

The monoterpene mixing ratios were in the order of $0.05 \mathrm{ppbv}$ in the winter and almost an order of magnitude higher, in the order of $0.3 \mathrm{ppbv}$, in the summers (Table 3 , Fig. 8). High momentary peaks were characteristic for the monoterpene mixing ratio. The peaks values elevated the winter mixing ratio average to $0.09 \mathrm{ppbv}$, which is close to values determined with one hour adsorbent samples and GC-MS analysis at midday during winter (Hakola et al., 2003). The spring time levels of monoterpenes were similar to those observed continuously with a similar method (Sellegri et al., 2005) and with midday adsorbent samples and GC-MS analysis (Spanke et al., 2001). The summer monoterpene mixing ratios were also in the same order of magnitude as determined previously (Hakola et al., 2003; Spanke et al., 2001; Rinne et al., 2005). Monoterpenes are emitted by the surrounding Scots pine and Norway spruce forests. The emissions are much higher during summer and very small during winter, however, monoterpene lifetime is longer in winter (Hakola et al., 2003).

The monoterpene volume mixing ratio peaks, that were an order of magnitude higher 25 than the median volume mixing ratios, occurred throughout the year but more frequently during the summers (Fig. 7). The seasonal and general behaviors of monoterpene and benzene mixing ratios were different, as expected for compounds that are dominated by different sources and sinks (Fig. 9). However, sometimes we observed simultaneously elevated monoterpene and benzene volume mixing ratios (Figs. 8-10).

VOC concentrations: annual cycle in boreal forest

T. M. Ruuskanen et al.

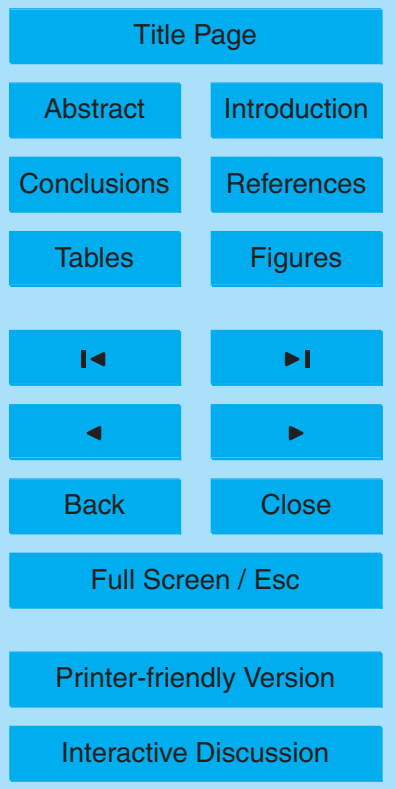

Interactive Discussion 
Since benzene originates from anthropogenic processes and biomass burning, the simultaneous high monoterpene mixing ratios were likely to be of similar origin. However, these periods when the monoterpene and benzene, and in fact all VOC, mixing ratios peaked simultaneously were short, and the only summer time event that lasted

5 for days was in August 2006 (Figs. 4-8). Similar situation occurred in August 2007, but at that time the highest monoterpene mixing ratios were measured before elevation of the benzene volume mixing ratio.

The acetonitrile volume mixing ratio was measured since March 2007 (Table 3, Fig. 4). The highest acetonitrile mixing ratios were between 0.1 and $0.2 \mathrm{ppbv}$. The 10 median volume mixing ratio was $0.04 \mathrm{ppbv}$, similar values were measured in spring 2003 (Sellegri et al., 2005). Acetonitrile is mainly emitted from anthropogenic sources for example in industrial processes, car exhaust and biomass burning. In addition, acetonitrile is used to associate air mass with wild fires since it is also produced in biomass burning (de Gouw et al., 2003b). At the time of the measurements (summer and spring 15 2007) the acetonitrile volume mixing ratio did not show large variations, except August 2007 when all measured VOC mixing ratios peaked. Acetonitrile remained in the order of magnitude of atmospheric background concentration and we could not identify fresh biomass burning plumes.

The sum of hexanal and cis-3-hexenol volume mixing ratios over the whole measurement period were in the order of 1 ppbv (Table 3, Fig. 7), similar values for hexanal have been measured with other methods at the same site (Hellén et al., 2004). The hexanal and cis-3-hexenol median was lowest in September 0.45 ppbv in 2006 and 0.22 ppbv in 2007 and highest in April when the median was 1.88 ppbv. These $\mathrm{C}_{6}$ compounds are emitted from wounded plants, but hexanal is also emitted from anthropogenic sources 25 such as vehicular exhaust (Schauer et al., 2002) and it is produced in the air as a result of oxidation of $n$-alkanes (Ciccioli and Mannozzi, 2007).

The acetaldehyde and MACR-MVK (Figs. 5 and 7) volume mixing ratios had only slight seasonality and MEK (Fig. 8) did not have any at all. The medians were 0.24 , 0.09 and 0.09 ppbv, respectively (Table 3, Figs. 7 and 8 ). The acetaldehyde volume

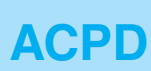

9, 81-134, 2009

VOC concentrations: annual cycle in boreal forest

T. M. Ruuskanen et al.

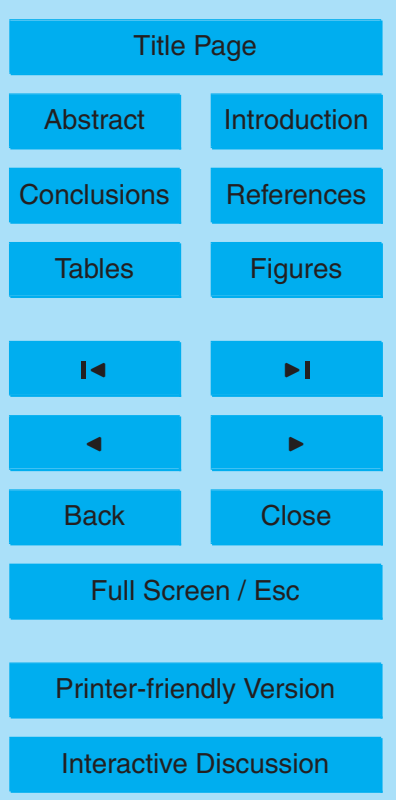


mixing ratio was highest during summer months, the median was $0.39 \mathrm{ppbv}$ in 2006 and 0.25 ppbv in 2007, and lowest in December-January, when the median was $0.16 \mathrm{ppbv}$. During a measurement campaign in March 2003 Sellegri et al. (2005) measured order of magnitude lower volume mixing ratios of acetaldehyde. However, simultaneously 5 Hellén et al. (2004) determined values similar to ours. The MACR-MVK volume mixing ratio median was highest during the summers, $0.19 \mathrm{ppbv}$ in June 2006 , and $0.15 \mathrm{ppbv}$ in August 2007, and lowest $0.06 \mathrm{ppbv}$ in winter months. Similar spring MACR-MVK values were measured by Sellegri et al. (2005). Hakola et al. (2003) measured similar and constant MACR-MEK mixing ratios throughout the year, indicating a summer 10 source from isoprene oxidation and an anthropogenic source in winter. The MEK volume mixing ratio median was $0.09 \mathrm{ppbv}$ over the whole period and lowest $0.07 \mathrm{ppbv}$ during November-February. Hellén et al. (2004) measured 0.2 ppbv for MEK in March 2003 at the same site, which is at the upper level of the spring mixing ratios in this study.

15 Most of the biogenic emissions come from the trees of surrounding forests. However, coniferous needle litter can be an important VOC source. In addition to monoterpene and sesquiterpene emissions from the evaporating storage pools, several carbonyls and alcohols, including acetone, have been measured from the decomposing needles (Isidorov et al., 2003). Highest acetone and methanol emission rates by litter are observed in late spring and at the beginning of fall (Warneke et al., 1999). Winter and spring emissions may be influenced by emissions from cutting down of trees and logging waste (branches and tree stumps) remaining in the surroundings of the measurement site. In February-April 2006 timber logging was done within 1.5 to $2.5 \mathrm{~km}$ distance in total area of some $13 \mathrm{ha}$ and in spring 2007 some 8 ha within $0.8-3.5 \mathrm{~km}$ distance. Tree stumps have been observed to emit VOCs, but when compared to the emissions from the living foliage the emissions from stumps are of the order of few percent or less (Hakola et al., 2008).

The benzene volume mixing ratios were below $0.5 \mathrm{ppbv}$, highest in the winter, in February the median was $0.19 \mathrm{ppbv}$, and lowest during the summers, in June-July the

VOC concentrations: annual cycle in boreal forest

T. M. Ruuskanen et al.

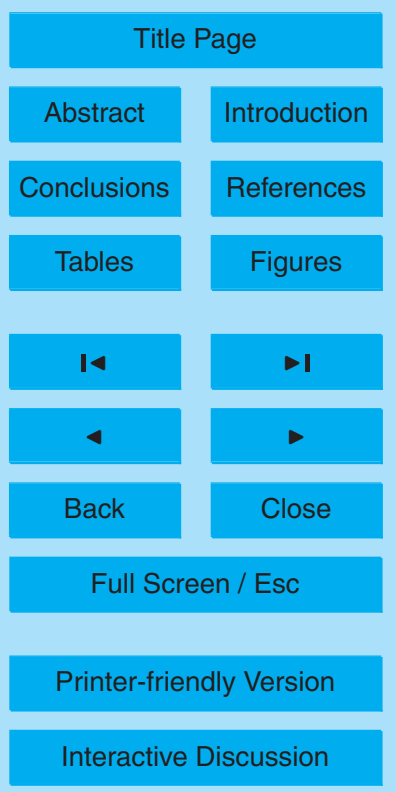

Interactive Discussion 
median was 0.06 ppbv in 2006 and 0.04 ppbv in 2007 (Table 3, Fig. 8). Benzene is emitted all year round from anthropogenic sources, such as incomplete combustion in vehicles and heating. Benzene has a long lifetime enabling long range transport. The main removal process is oxidization by $\mathrm{OH}$ which is suppressed during the dark winter.

5 The benzene volume mixing ratio begun decreasing in the spring when increasing solar radiation, further enhanced by reflection from snow covered surfaces, started photochemistry. Hakola et al. (2003) measured at the same site similar seasonality and benzene ratios as in this study.

We associated the summer increase in methanol, acetone, isoprene-MBO, monoter10 penes and $\mathrm{C}_{6}$-compounds to biogenic emissions, since the anthropogenic and biomass burning markers, benzene and acetonitrile, were low during the summers (Figs. 4, 5, 7, 8 and 10). However, we could not exclude anthropogenic influence on the momentary peaks in the monoterpene mixing ratios. Differences in the behaviors of compounds with important biogenic emissions can be explained by differences in their lifetimes, 15 sources and emissions. During summer the lifetimes of isoprene and monoterpenes are in the order of an hour or a few hours due to daytime reaction with $\mathrm{OH}$, nighttime reaction with $\mathrm{NO}_{3}$ and diurnal oxidation by ozone (Rinne et al., 2007). Methanol and acetone, on the other hand, react slower and are not oxidized by ozone (Rinne et al., 2007). Methanol has a lifetime of a few days during daytime reaction with $\mathrm{OH}$ and it is not oxidized at night. Acetone is slowly removed by $\mathrm{OH}$ and photolysis during days resulting in an estimated lifetime of 8 days. Due to very low concentration of $\mathrm{NO}_{3}$ (Hakola et al., 2003), acetone has a night lifetime of 17 years. The long lifetimes of methanol and acetone (Rinne et al., 2007) results in a higher background concentration where as terpenoids are removed within several hours after emissions. Monoterpenes, 25 methanol, acetone and MBO have local direct biogenic emissions, however, isoprene is not emitted at the measurement spot but from a regional source and chemical reactions occur before it reaches the measurement point. The emissions are governed by different environmental parameters. The emissions of monoterpenes are described by a temperature algorithm, while the other BVOC emissions are expected to be also

VOC concentrations: annual cycle in boreal forest

T. M. Ruuskanen et al.

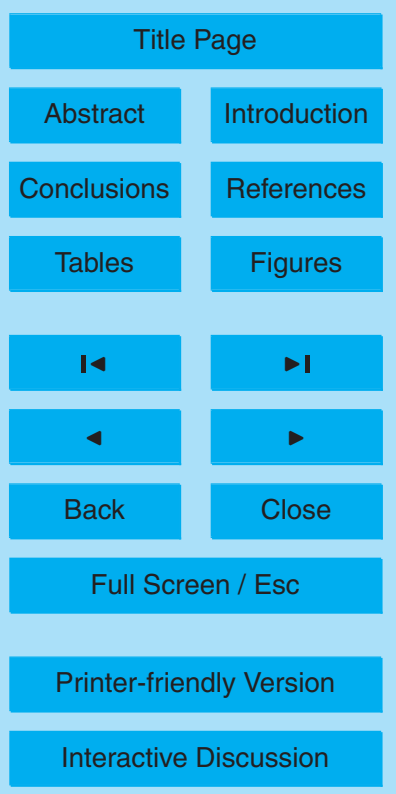

Interactive Discussion 
affected by solar radiation.

\subsection{Diurnal variation}

The diurnal variation of solar radiation, temperature and mixing time scale (Fig. 11) affect volume mixing ratios of VOCs (Fig. 12). Local BVOC emissions depend on tem5 perature and light. The sinks of the VOCs, as well, depend on the available solar radiation: oxidation by $\mathrm{OH}$ and ozone occurs during light hours, while ozone and $\mathrm{NO}_{3}$ reactions take place in dark. Turbulence is expressed with above canopy mixing time scale $z / u^{*}$, where $z$ is the measurement height of $14 \mathrm{~m}$ above ground level and $u^{*}$ the friction velocity. The day to night variation of VOC mixing ratios reflect meteorological changes as well as fast changes in photosynthetic activity. The seasonal changes reflect seasonality of the meteorology as well as slower seasonal changes in plant activity such as spring recovery, various growth periods during summer, hardening and litter decomposition in fall, and dormancy in winter.

Summer and spring days are flooded with light (Fig. 11), summer days are long, the sun rises around $4 \mathrm{am}$ and sets around $10 \mathrm{pm}$ LT. The maximum summer photosynthetical photon flux density (PPFD) median was $1250 \mu \mathrm{mol} \mathrm{m}^{-2} \mathrm{~s}^{-1}$ during 2006. However, summer 2007 was cloudier, corresponding median was only $950 \mu \mathrm{mol} \mathrm{m}^{-2} \mathrm{~s}^{-1}$. This difference in the summers was also seen in precipitation. Accumulated precipitation was only $80 \mathrm{~mm}$ during the summer 2006, on the other hand during the cloudier and 20 rainier summer 2007 accumulated precipitation was $210 \mathrm{~mm}$. During the spring the PPFD was in the same order of magnitude as in the summers, since in the spring the solar radiation was enhanced by reflecting snow cover. By contrast to spring and summer, winter days were dark and the sun shone at a low solar angle between $10 \mathrm{am}$ and $4 \mathrm{pm} \mathrm{LT}$, the winter maximum PPFD median was only $100 \mu \mathrm{mol} \mathrm{m}^{-2} \mathrm{~s}^{-1}$. This seasonality was reflected in temperature and mixing time scale that did not have a systematic diurnal course during winter days. During summer days, on the contrary, temperature and turbulence, expressed as shorter mixing time scale, clearly followed the solar radiation. Mixing was fastest in the afternoon and slowest during night, before sunrise.

VOC concentrations: annual cycle in boreal forest

T. M. Ruuskanen et al.

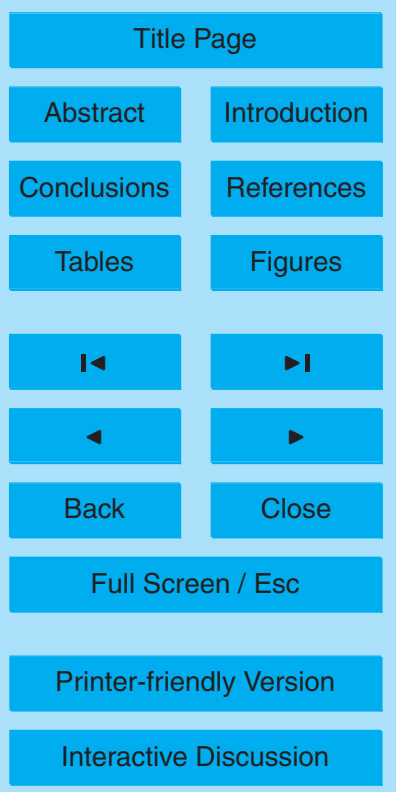


The spring and summer 2006 day median temperature variation was $10^{\circ} \mathrm{C}$, but only $7^{\circ} \mathrm{C}$ during the cloudier summer 2007 . The diurnal variation of mixing time scale was also larger during 2006 than 2007.

The seasonality was also seen in the diurnal variation of the VOC volume mixing 5 ratios, especially for locally emitted biogenic compounds. The diurnal variation was largest in the summers, while in the winter the volume mixing ratios remained quite constant. During the summers the volume mixing ratios of isoprene-MBO and monoterpenes were an order of magnitude lower than those of methanol and acetone (Fig. 12). The diurnal variations of isoprene-MBO and monoterpene volume mixing ratios were 10 almost the same for both summers. However, the terpenoid mixing ratio levels were slightly higher in the sunnier summer 2006 . In contrast, the volume mixing ratios of methanol, acetaldehyde and acetone were higher during the summer 2006 and their diurnal patterns varied annually. The benzene volume mixing ratios did not show clear diurnal variation in any season.

15 Isoprene concentration measurements show usually diurnal pattern with maximum at 18:00 UT (Goldan et al., 1995; Biesenthal et al., 1998; Warneke et al., 2001b) due to isoprenes temperature and light dependent emissions and removal at night time. Like for isoprene, MBO emissions are temperature and light dependent and similar diurnal patterns are expected. The isoprene-MBO volume mixing ratio in the present study peaked approximately at the same time as in earlier studies, a few hours before sunset (Figs. 11 and 12). The diurnal pattern of monoterpene volume mixing ratios in the summers had a minimum in day and a maximum at night (Fig. 12). Similar variability was also measured by Hakola et al. (2000) and Rinne et al. (2005) during the whole growing season and by Spanke et al. (2001) during late summer. In spring measurements Sellegri et al. (2005) observed a nighttime maximum and two additional secondary daily maxima.

The monoterpene volume mixing ratios were highest during summer nights when temperature dependent emissions of monoterpenes are low and mixing is lowest. However, other BVOC, methanol, acetaldehyde, acetone and isoprene, mixing ratios were

9, 81-134, 2009

VOC concentrations: annual cycle in boreal forest

T. M. Ruuskanen et al.

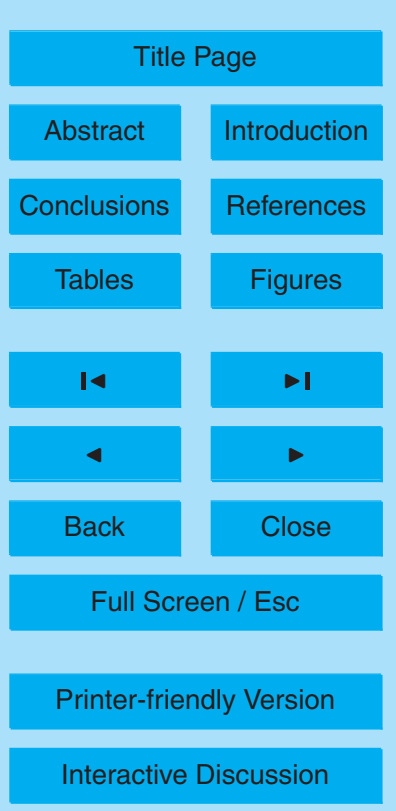


highest during summer in the late evening before sunset and end of light dependent emissions.

The shape of the biogenic VOC diurnal pattern is determined by: 1) emission and formation processes, 2) removal processes and 3) mixing. In addition to biogenic emis5 sions monoterpenes, isoprene, methanol, acetone, and acetaldehyde are emitted from anthropogenic sources. The hemiterpenoid (isoprene-MBO) and monoterpene lifetime is in the order of half an hour to a few hours (Rinne et al., 2007) and thus the terpenoid emissions were local or regional. Methanol and acetone, on the other hand, have longer lifetimes in the order of days (Rinne et al., 2007) and thus they can travel long 10 distances. In addition to the biogenic and anthropogenic emissions methanol, acetone and acetaldehyde are produced locally by photo-oxidation of other compounds, e.g. isoprene is oxidized to acetone (Singh et al., 2000).

Biogenic emissions are driven by different environmental factors with different diurnal cycles. The light and temperature dependent emissions (such as isoprene, Guenther 15 et al., 1995; and MBO, Hakola et al., 2006) are highest at midday and go to zero when the sun sets, while the temperature dependent emissions (such as monoterpenes, Hakola et al., 2006) are highest at late afternoon and decline until sunrise but do not totally cease. Isoprene is emitted directly after synthesis and thus the emissions follow PPFD (Figs. 11 and 12). Water soluble methanol is mainly emitted through the stomata (Nemecek-Marshall et al. 1995; Niinemets and Reichstein, 2003). Since opening of the stoma follows light also methanol emissions (Fig. 12) follow measured PPFD (Fig. 11). However, there are differences in the light dependent emissions. Niinemets and Reichstein (2003) link it to partitioning between water and gas phase. Emissions of compounds with high water solubility, such as methanol, can be controlled by stomatal opening unlike less water soluble isoprene and monoterpenes. Harley et al. (2007) observed stomatal and temperature controlled methanol emission as well as methanol emission burst after dark periods as predicted by Niinemets and Reichstein (2003). Janson and de Serves (2001) determined acetone emissions to be temperature dependent in a similar way to monoterpene emissions from Scots pine and Norway spruce.

9, 81-134, 2009

VOC concentrations: annual cycle in boreal forest

T. M. Ruuskanen et al.

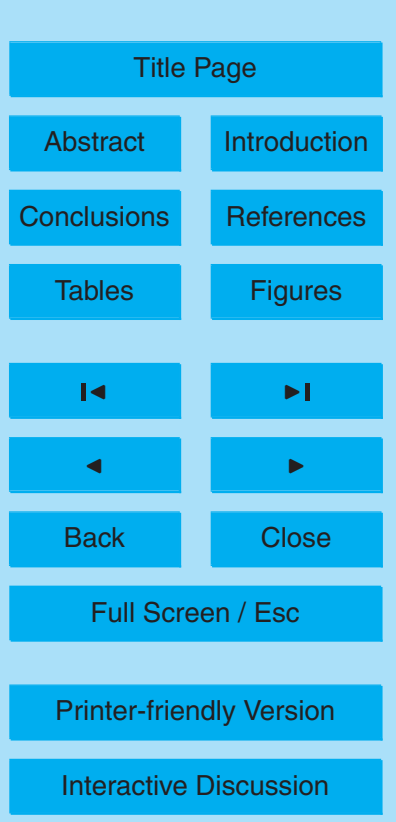

Interactive Discussion 
Removal processes such as, photochemical oxidation by $\mathrm{OH}$-radical (such as reaction of acetaldehyde, Hellén et al., 2004) or day and night time reactions (such as oxidation of isoprene by $\mathrm{OH}$ and ozone, Atkinson and Arey, 2003) have diurnal patters. Rinne et al. (2007) estimated lifetimes for summer at the same site taking into account $\mathrm{OH}$, $5 \mathrm{O}_{3}, \mathrm{NO}_{3}$ and photolysis during day and $\mathrm{NO}_{3}$ and $\mathrm{O}_{3}$ during night. The main BVOCs can be divided into two groups, terpenoids have lifetimes in the order of hours around the clock while methanol and acetone react during daylight hours with slower lifetimes of several days (Rinne et al., 2007). The MBO behaves similar to the terpenoids, isoprene and monoterpenes, and is oxidized with $\mathrm{OH}$ and ozone during day and ozone 10 and nitrate radical at night (Fantechi et al., 1998). Dilution and transportation of emitted compounds has a diurnal pattern since turbulence is driven by solar radiation. When the sun rises, mixing is increased leading to lower concentration if the local emission and deposition remain constant. Respectively, as the solar radiation is decreased, nocturnal inversion can lead to accumulation.

15 The annual variation of the VOC mixing ratios was not only due to the observed annual differences in local meteorology (Fig. 11). The carbon monoxide (CO), nitrous oxides $\left(\mathrm{NO}_{\mathrm{x}}\right)$ and benzene volume mixing ratios were higher during the summer 2006 indicating stronger anthropogenic influence. This would have also meant more long range transport of long lived anthropogenic VOCs such as benzene, methanol and acetone. Higher solar radiation was assumed to have led to more active photochemistry in 2006, and more local secondary production of methanol, acetone and acetonitrile from photo-oxidation of other VOCs. The ozone concentration was higher in the summer 2006, and it is likely that also daytime $\mathrm{OH}$ concentrations were higher. In the absence of measurements we can not confirm inter-annual differences of $\mathrm{OH}$ radical concentrations. However, we did measure higher solar radiation and water vapor content in summer 2006, both are factors driving $\mathrm{OH}$ radical formation.

The annual differences effecting measured VOC mixing ratios (Fig. 13) were that the summer 2006 1) was slightly warmer, 2) had more solar radiation, and 3) had more anthropogenic influence in air mass. The observed about $15 \%$ difference in monoterpene

VOC concentrations: annual cycle in boreal forest

T. M. Ruuskanen et al.

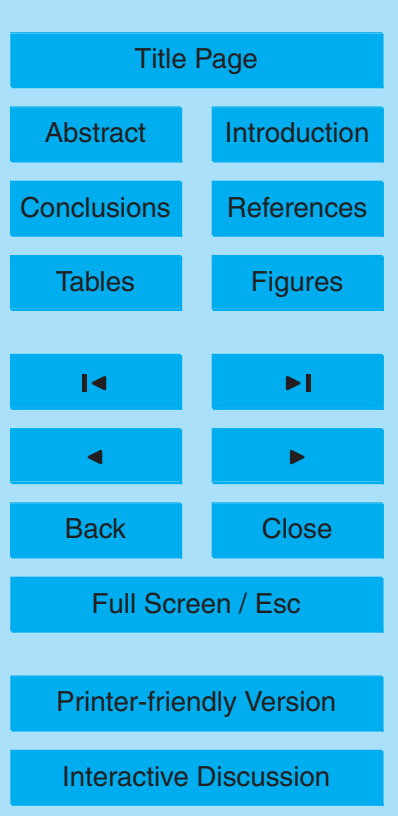


mixing ratio levels between the summers could be explained by small difference in the temperature. The about $20 \%$ annual difference in the levels of isoprene-MBO could be explained by an increase of biogenic emissions due to increase in both temperature and solar radiation. Methanol, acetone and acetaldehyde volume mixing ratio levels 5 were increased by $30-100 \%$ as a sum increased biogenic emissions, anthropogenic long range transport and secondary production.

\section{Conclusions}

Ambient VOC concentrations vary diurnally, seasonally and inter-annually. In order to represent VOC concentrations accurately, long-term measurements with sufficient 10 temporal resolution to observe diurnal patterns are needed. This requires automated VOC measurements, systematic calibration and explicit volume mixing ratio calculation procedures. For over a 15 month measurement period a PTR-MS was successfully used for online automated ambient VOC volume mixing ratio measurements. However, frequent background signal measurements and systematic calibrations as well as 15 maintenance are essential for reliable VOC volume mixing ratio measurements. Sensitivity of measurements for volume mixing ratios is weakened as the SEM detector ages. At first only the signal of heavier compounds is weakened while light compounds are still measured accurately. To obtain accurate volume mixing ratios and prevent mass bias frequent checking and readjustment of SEM operation voltage is essential. 20 In our continuous measurements we observed that the PTR-MS has to be calibrated and SEM operation voltage checked regularly, at least twice a month.

Methanol and acetone were the most abundant VOCs observed. Their median volume mixing ratios were in the order of 1 ppbv during the 15 month measurement period from June 2006 to September 2007. Methanol, acetone, isoprene-MBO and monoterpenes volume mixing ratios were highest during summer and lowest in winter. Benzene, dominated by anthropogenic emissions and photochemical removal, behaved the opposite way. The benzene volume mixing ratio median was 0.14 ppbv during win-

VOC concentrations: annual cycle in boreal forest

T. M. Ruuskanen et al.

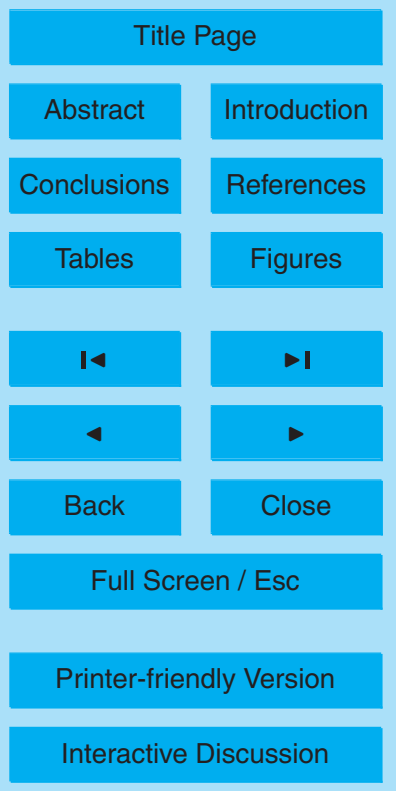


ter and less than half during summers. Seasonality of acetaldehyde and MACR-MVK volume mixing ratios were less profound. Biogenic VOC, methanol, acetone, isopreneMBO and monoterpene volume mixing ratios had clear diurnal patterns during summers while other VOCs did not have this behavior. During winter we did not observe 5 systematical diurnal cycle of the VOCs volume mixing ratios. In summer the diurnal monoterpene maximum was typically during nights between sunset and sunrise, while methanol, acetone, acetaldehyde and isoprene-MBO volume mixing ratios were highest before sunset. The monoterpenes and hemiterpeneoids (isoprene-MBO) had an order of magnitude lower volume mixing ratios than methanol and acetone. The ter10 penoids have shorter lifetimes and they were dominated by local emissions. Methanol and acetone have relatively long lifetimes and in addition to local sources have contributions from long range transport of anthropogenic emissions as well as from secondary production from oxidation of other VOCs. The measured volume mixing ratios could be qualitatively explained by considering sources, removal processes and turbulent mix15 ing. However, the detailed atmospheric chemistry is beyond the scope of this paper and will be in future studied using comprehensive chemistry models such as MALTE (Boy et al., 2006).

\section{Appendix A}

Monthly averages, medians, 5 and 95 percentiles of methanol (M33), acetonitrile 20 (M42), acetaldehyde (M45), acetone (M59), isoprene-MBO (M69), MACR-MVK (M71), MEK (M73), benzene (M79), hexanal - cis-3-hexenol (M101) and monoterpene (M137) volume mixing ratios and number of hours when measurements were done. Data was calculated using hourly averages, from ambient air measurements at $14 \mathrm{~m}$ height at SMEAR II station.

25 Acknowledgement. We thank the staff of SMEAR II station for their assistance in our measurements and J. Patokoski for her contribution in data processing. We acknowledge the Academy

9, 81-134, 2009

VOC concentrations: annual cycle in boreal forest

T. M. Ruuskanen et al.

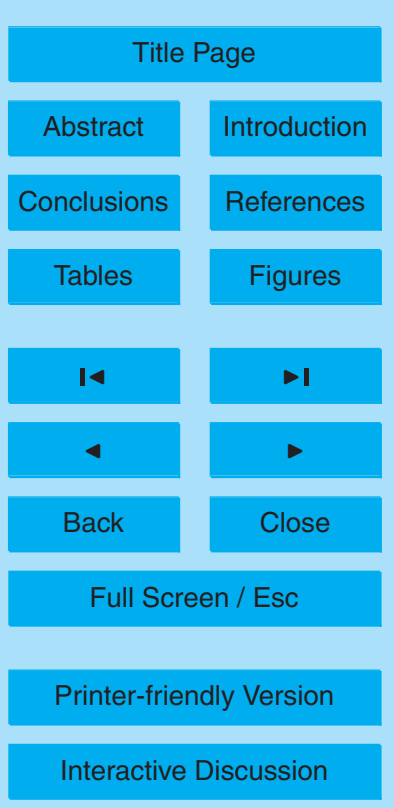

Interactive Discussion 
of Finland (projects 209216, 120434, 125238), the Helsinki University of Helsinki Environmental Research Center (Urban and Rural Air Pollution Consortium) and the Kone Foundation.

\section{ACPD}

9, 81-134, 2009

\section{References}

Ammann, C., Spirig, C., Neftel, A., Steinbacher, M., Komenda, M., and Schaub, A.: Application of PTR-MS for measurements of biogenic VOC in a deciduous forest, Int. J. Mass Spectrom., 239, 87-101, 2004.

Atkinson, R. and Arey, J.: Atmospheric degradation of volatile organic compounds, Chem. Rev., 103, 4605-4638, 2003.

Biesenthal, T. A., Bottenheim, J. W., Shepson, P. B., Li, S.-M., and Brickell, P. C.: The chemistry 10 of biogenic hydrocarbons at a rural site in eastern Canada, J. Geophys. Res., 103, $25487-$ 25 498, 1998.

Boudries, H., Bottenheim, J. W., Guimbaud, C., Grannas, A. M., Shepson, P. B., Houdier, S., Perrier, S., and Domine, F.: Distribution and trends of oxygenated hydrocarbons in the high Arctic derived from measurements in the atmospheric boundary layer and interstitial snow air during the ALERT2000 field campaign, Atmos. Environ., 36, 2573-2583, 2002.

Boy, M., Hellmuth, O., Korhonen, H., Nilsson, E. D., ReVelle, D., Turnipseed, A., Arnold, F., and Kulmala, M.: MALTE model to predict new aerosol formation in the lower troposphere, Atmos. Chem. Phys., 6, 4499-4517, 2006, http://www.atmos-chem-phys.net/6/4499/2006/.

Ciccioli, P. and Mannozzi, M.: High-Molecular-Weight Carbonyls and Carboxylic Acids. In: Koppmann R., (ed.) Volatile Organic Compounds in the Atmosphere. Blackwell Publishing, ISBN: 978-1-4051-3115-5, 2007.

Crutzen, P. J, Williams, J., Poschl, U., Hoor, P., Fischer, H., Warneke, C., Holzinger, R., Hansel, A., Lindinger, W., Scheeren, B., and Lelieveld, J.: High spatial and temporal resolution measurements of primary organics and their oxidation products over the tropical forests of Surinam, Atmos. Environ., 34, 1161-1165, 2000.

Fall, R., Karl, T., Hansel, A., Jordan, A., and Lindinger, W.: Volatile organic compounds emitted after leaf wounding: On-line analysis by proton-transfer-reaction mass spectrometry, J. Geophys. Res., 104, 15963-15974, 1999.

Fantechi, G., Jensen, N. R., Hjorth, J., and Peeters, J.: Mechanistic studies of the atmospheric
VOC concentrations: annual cycle in boreal forest

T. M. Ruuskanen et al.

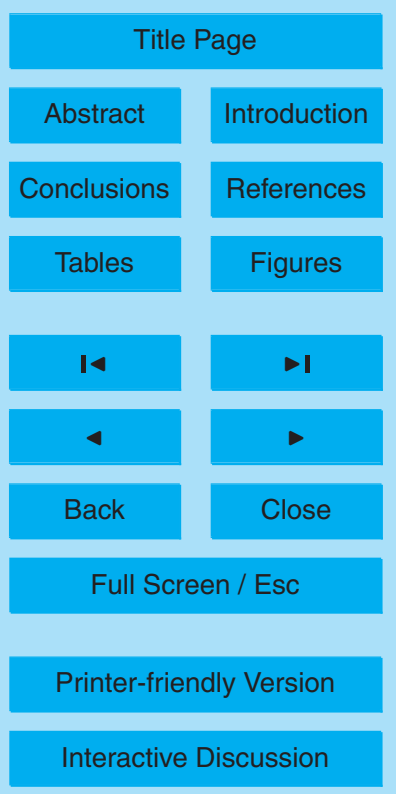


oxidation of methyl butenol by $\mathrm{OH}$ radicals, ozone and $\mathrm{NO}_{3}$ radicals, Atmos. Environ., 32, 3547-3556, 1998.

Fehsenfeld, F., Calvert, J., Fall, R., Goldan, P., Guenther, A. B, Hewitt, C.N., Lamb, B., Liu, S., Trainer, M., Westberg, H., and Zimmermann, P.: Emissions of volatile organic compounds 5 from vegetation and the implications for atmospheric chemistry, Global Biogeochem. Cy., 6, 389-430, 1992.

de Gouw, J. and Warneke, C.: Measurements of volatile organic compounds in the Earth's atmosphere using proton-transfer-reaction mass spectrometry, Mass Spectrom. Rev., 26, 223-257, 2007.

10 de Gouw, J. A., Goldan, P. D., Warneke, C., Kuster, W. C., Roberts, J. M., Marchewka, M., Bertman, S. B., Pszenny, A. A. P., and Keene, W. C.: Validation of proton transfer reaction-mass spectrometry (PTR-MS) measurements of gas-phase organic compounds in the atmosphere during the New England Air Quality Study (NEAQS) in 2002, J. Geophys. Res., 108(D21), 4682, doi:10.1029/2003JD003863, 2003.

de Gouw, J., Warneke, C., Karl, T., Eerdekens, G., van der Veen, C., and Fall, R.: Sensitivity and specificity of atmospheric trace gas detection by proton-transfer-reaction mass spectrometry, Int. J. Mass Spectrom., 223-224, 365-382, 2003.

de Gouw, J. A, Warneke, C., Parrish, D. D, Holloway, J. S, Trainer, M., and Fehsenfeld, F. C: Emission sources and ocean uptake of acetonitrile $\left(\mathrm{CH}_{3} \mathrm{CN}\right)$ in the atmosphere, J. Geophys.

20 Res., 108(D11), 4329, doi:10.1029/2002JD002897, 2003b.

de Gouw, J., Warneke, C., Holzinger, R., Klüpfel, T., and Williams, J.: Inter-comparison between airborne measurements of methanol, acetonitrile and acetone using two differently configured PTR-MS instruments, Int. J. Mass Spectrom., 239, 129-137, 2004.

Goldan, P. D., Kuster, W., and Fehesenfeld, F.: The observation of a C5 alcohol emission in North American pine forest, Geophys. Res. Lett., 20, 1039-1042, 1993.

Guenther, A., Hewitt, C. N, Erickson, D., Fall, R., Geron, C., Graedel, T., Harley, P., Klinger, L., Lerdau, M., McKay, W. A, Pierce, T., Scholes, B., Steinbrecher, R., Tallamraju, R., Taylor, J., and Zimmerman, P.: A global model of natural volatile organic compound emissions, J. Geophys. Res., 100, 8873-8892, 1995.

so Haapanala, S., Rinne, J., Hakola, H., Helln, H., Laakso, L., Lihavainen, H., Janson, R., O’Dowd, C., and Kulmala, M.: Boundary layer concentrations and landscape scale emissions of volatile organic compounds in early spring, Atmos. Chem. Phys., 7, 1869-1878, 2007, http://www.atmos-chem-phys.net/7/1869/2007/.

\section{ACPD}

9, 81-134, 2009

VOC concentrations: annual cycle in boreal forest

T. M. Ruuskanen et al.

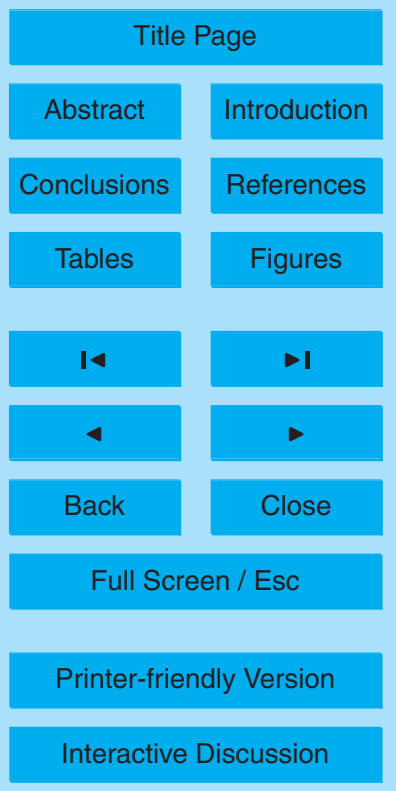


Haapanala, S., Rinne, J., Pystynen, K.-H., Hellén, H., Hakola, H., and Riutta, T.: Measurements of hydrocarbon emissions from a boreal fen using the REA technique, Biogeosciences, 3 , 103-112, 2006, http://www.biogeosciences.net/3/103/2006/.

5 Hakola, H., Rinne, J., and Laurila, T.: The Hydrocarbon Emission Rates of Tea-Leafed Willow (Salix Phylicifolia), Silver Birch (Betula Pendula) and European Aspen (Populus Tremula), Atmos. Environ., 32(10), 1825-1833, 1998.

Hakola, H., Laurila, T., Rinne J., and Puhto, K.: The ambient concentrations of biogenic hydrocarbons at a northern European, boreal site, Atmos. Environ., 34, 4971-4982, 2000.

10 Hakola, H., Tarvainen, V., Laurila, T., Hiltunen, V., Hellén, H., and Keronen, P.: Seasonal variation of VOC concentrations above a boreal coniferous forest, Atmos. Environ., 37, 16231634, 2003.

Hakola, H., Tarvainen, V., Bck, J., Ranta, H., Bonn, B., Rinne, J., and Kulmala, M.: Seasonal variation of mono- and sesquiterpene emission rates of Scots pine, Biogeosciences, 3, 93101, 2006, http://www.biogeosciences.net/3/93/2006/.

Hakola, H., Haapanala, S., Rinne, J., Vestenius, M., and Tarvainen V.: VOC Emissions from Tree Stumps, Report Series in Aerosol Science, 93, 33-36, 2008.

Hari, P., and Kulmala, M.: Station for Measuring Ecosystem-Atmosphere Relations (SMEAR II), Boreal Environ. Res., 10, 315-322, 2005.

Harley, P., Greenberg, J., Niinemets, Ü., and Guenther, A.: Environmental controls over methanol emission from leaves, Biogeosciences, 4, 1083-1099, 2007, http://www.biogeosciences.net/4/1083/2007/.

Heikes, B. G, Chang, W. N, Pilson, M. E. Q, Swift, E., Singh, H. B, Guenther, A., Jacob, D. J, Field, B. D, Fall, R., Riemer, D., and Brand, L.: Atmospheric methanol budget and ocean implication, Global Biogeochem. Cy., 16, 1133, doi:10.1029/2002GB001895, 2002.

Hellén, H., Hakola, H., Reissell, A., and Ruuskanen, T. M.: Carbonyl compounds in boreal coniferous forest air in Hyytiälä, Southern Finland, Atmos. Chem. Phys., 4, 1771-1780, 2004, http://www.atmos-chem-phys.net/4/1771/2004/.

30 Hellén, H., Hakola, H., Pirjola, L., Laurila, T., and Pystynen, K.-H.: Ambient air concentrations, source profiles, and source apportionment of 71 different $\mathrm{C} 2-\mathrm{C} 10$ volatile organic compounds in urban and residential areas of Finland, Environ. Sci. Technol., 40, 103-108, 2006.

Holzinger, R., Kleiss, B., Donoso, L., and Sanhuez, E.: Aromatic hydrocarbons at urban, sub-

VOC concentrations: annual cycle in boreal forest

T. M. Ruuskanen et al.

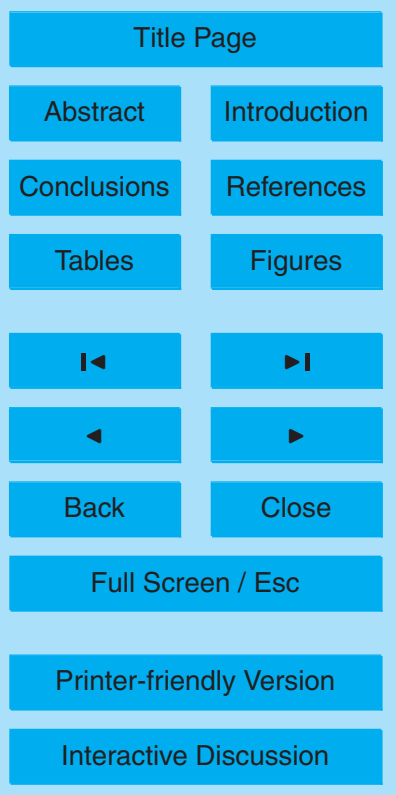


urban, rural (81520N; 671190W) and remote sites in Venezuela, Atmos. Environ., 35, 49174927, 2001.

Holzinger, R., Lee, A., McKay, M., and Goldstein, A. H.: Seasonal variability of monoterpene emission factors for a ponderosa pine plantation in California, Atmos. Chem. Phys., 6, 12671274, 2006, http://www.atmos-chem-phys.net/6/1267/2006/.

Isidorov, V. A, Vinogorova, V. T, and Rafalowski, K.: HS-SPME analysis of volatile organic compounds of coniferous needle litter, Atmos. Environ., 37, 4645-4650, 2003.

Janson, R. and de Serves, C.: Acetone and monoterpene emissions from boreal forest in northern Europe, Atmos. Environ., 35, 4629-4637, 2001.

Karl, T., Guenther, A., Spirig, C., Hansel, A., and Fall, R.: Seasonal variation of biogenic VOC emissions above a mixed hardwood forest in northern Michigan, Geophys. Res. Lett., 30, 2186, doi:10.1029/2003GL018432, 2003.

Karl, T., Crutzen, P. J., Mandl, M., Staudinger, M., Guenther, A., Jordan, A., Fall, R., and 15 Lindinger, W.: Variability-lifetime relationship of VOCs observed at the Sonnblick Observatory 1999-estimation of HO-densities, Atmos. Environ., 35, 5287-5300, 2001.

Kourtchev, I., Ruuskanen, T., Maenhaut, W., Kulmala, M., and Claeys, M.: Observation of 2methyltetrols and related photo-oxidation products of isoprene in boreal forest aerosols from Hyytiälä, Finland, Atmos. Chem. Phys., 5, 2761-2770, 2005,

20 http://www.atmos-chem-phys.net/5/2761/2005/.

Kroll, J. H. and Seinfeld, J. H: Chemistry of secondary organic aerosol: Formation and evolution of low-volatility organics in the atmosphere, Atmos. Environ., 42(16), 3593-3624, 2008.

Kulmala, M., Suni, T., Lehtinen, K. E. J., Dal Maso, M., Boy, M., Reissell, A., Rannik, ., Aalto, P., Keronen, P., Hakola, H., Bäck, J., Hoffmann, T., Vesala, T., and Hari, P.: A new feedback mechanism linking forests, aerosols, and climate, Atmos. Chem. Phys., 4, 557-562, 2004, http://www.atmos-chem-phys.net/4/557/2004/.

Lindfors, V., Laurila, T., Hakola, H., Steinbrecher, R., and Rinne, J.: Modeling speciated terpenoid emissions from the European boreal forest, Atmos. Environ., 34, 4983-4996, 2000.

Lindinger, W., Hansel, A., and Jordan, A.: On-line monitoring of volatile organic compounds

30 at pptv levels by means of Proton-Transfer-Reaction Mass Spectrometry (PTR-MS) Medical applications, food control and environmental research, Int. J. Mass Spect. Ion Proc., 173, 191-241, 1998.

Nemecek-Marshall, M., MacDonald, R. C, Franzen, J. J, Wojciechowski, C. L, and Fall, R.:

VOC concentrations: annual cycle in boreal forest

T. M. Ruuskanen et al.

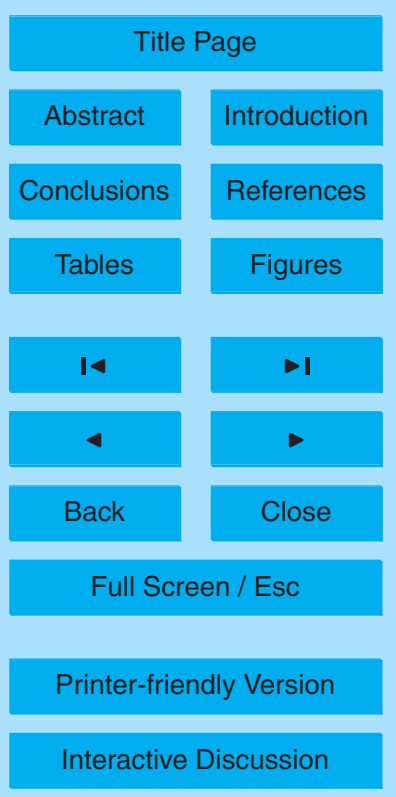


Methanol emission from leaves. Enzymic detection of gas-phase methanol and relation of methanol fluxes to stomatal conductance and leaf development, Plant Physiol., 108, 135968, 1995.

Niinemets, Ü. and Reichstein, M.: Controls on the emission of plant volatiles through stomata: 5 Differential sensitivity of emission rates to stomatal closure explained, J. Geophys. Res., 108, 4208, doi:10.1029/2002JD002620, 2003.

Rinne, J., Ruuskanen, T. M, Reissell, A., Taipale, R., Hakola, H., and Kulmala, M.: On-line PTRMS measurements of atmospheric concentrations of volatile organic compounds in a European boreal forest ecosystem, Boreal Environ. Res., 10, 425-436, 2005.

10 Rinne, J., Taipale, R., Markkanen, T., Ruuskanen, T. M., Hellén, H., Kajos, M. K., Vesala, T., and Kulmala, M.: Hydrocarbon fluxes above a Scots pine forest canopy: measurements and modeling, Atmos. Chem. Phys., 7, 3361-3372, 2007, http://www.atmos-chem-phys.net/7/3361/2007/.

Ruuskanen, T. M., Kolari, P., Bäck, J., Kulmala, M., Rinne, J., Hakola, H., Taipale, R., Raivo15 nen, M., Altimir, N., and Hari, P.: On-line field measurements of monoterpene emissions from Scots pine by proton-transfer reaction mass spectrometry, Boreal Environ. Res., 10, 553-567, 2005.

Salisbury, G., Williams, J., Holzinger, R., Gros, V., Mihalopoulos, N., Vrekoussis, M., SardaEstève, R., Berresheim, H., von Kuhlmann, R., Lawrence, M., and Lelieveld, J.: Groundbased PTR-MS measurements of reactive organic compounds during the MINOS campaign in Crete, JulyAugust 2001, Atmos. Chem. Phys., 3, 925-940, 2003, http://www.atmos-chem-phys.net/3/925/2003/.

Schauer, J. J., Kleeman, M. J, Cass, G. R, and Simoneit, B. R. T: Measurement of emissions from air pollution sources, $5 . \mathrm{C}_{1}-\mathrm{C}_{32}$ organic compounds from gasoline powered vehicles, Environmental Science and Technology, 36, 1169-1180, 2002.

Schnitzhofer, R., Beauchamp, J., Dunkl, J., Wisthaler, A., Weber, A., and Hansel, A.: Longterm measurements of $\mathrm{CO}, \mathrm{NO}, \mathrm{NO}_{2}$, benzene, toluene and PM10 at a motorway location in an Austrian valley, Atmos. Environ. In Press, Corrected Proof, http://www.sciencedirect.com/ science/article/B6VH3-4PW05HX-5/2/8a38e2f4d535c5e2fc361c2a154324e7, 2008.

so Sellegri, K., Umann, B., Hanke, M., and Arnold, F.: Deployment of a ground-based CIMS apparatus for the detection of organic gases in the boreal forest during the QUEST campaign, Atmos. Chem. Phys., 5, 357-372, 2005, http://www.atmos-chem-phys.net/5/357/2005/.

VOC concentrations: annual cycle in boreal forest

T. M. Ruuskanen et al.

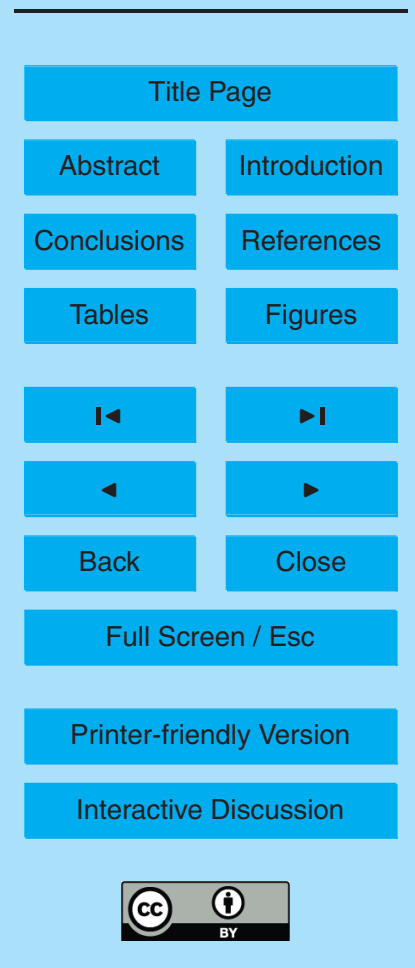


Simpson, D., Winiwarter, W., Börjesson, G., Cinderby, S., Ferreiro, A., Guenther, A., Hewitt, C. N., Janson, R., Khalil, M. A. K, Owen, S., Pierce, T.E., Puxbaum, H., Shearer, M., Skiba, U., Steinbrecher, R., Tarrasón, L., and Öquist, M. G: Inventorying Emissions from Nature in Europe, J. Geophys. Res., 104, 8113-8152, 1999.

5 Singh, H., Chen, Y., Tabazadeh, A., Fukui, Y., Bey, I., Yantosca, R., Jakob, D., Arnold, F., Wohlfrom, K., Atlas, E., Flocke, F., Blake, D., Heikes, B., Snow, J., Talbot, R., Gregory, G., Sachse, G., Vay, S., and Kondo, Y.: Distribution and fate of selected oxygenated organic species in the troposphere and lower stratosphere over Atlantic, J. Geophys. Res., 105, 3795-3805, 2000.

10 Singh, H. B., O'Hara, D., Herlth, D., Sachse, W., Blake, D. R., Bradshaw, J. D., Kanakidou, M., and Crutzen, P. J: Acetone in the atmosphere: distribution, sources and sinks, J. Geophys. Res., 99, 1805-1819, 1994.

Spanke, J., Rannik, U., Forkel, R., Nigge, W., and Hoffman, T.: Emission fluxes and atmospheric degradation of monoterpenes above a boreal forest: field measurements and modeling, Tel15 lus, 53B, 406-422, 2001.

Tulokas, R.: Environment Statistics 2005: Environment and Natural Resources 2005:2. Statistics Finland, Yliopistopaino, Helsinki, ISBN: 952-467-452-1, 2005.

Taipale, R., Ruuskanen, T. M., Rinne, J., Kajos, M. K., Hakola, H., Pohja, T., and Kulmala, M.: Technical Note: Quantitative long-term measurements of VOC concentrations by PTRMS - measurement, calibration, and volume mixing ratio calculation methods, Atmos. Chem. Phys., 8, 6681-6698, 2008, http://www.atmos-chem-phys.net/8/6681/2008/.

Tunved, P., Hansson, H.-C., Kerminen, V.-M., Ström, J., Dal Maso, M., Lihavainen, H., Viisanen, Y., Aalto, P. P., Komppula, M., and Kulmala, M.: High natural aerosol loading over boreal forests, Science, 312, 261-263, 2006.

Piccot, S. D., Watson, J. J., and Jones, J. W.: A global inventory of volatile organic compound emissions from anthropogenic sources, J. Geophys. Res., 97, 9897-9912, 1992.

Warneke, C., Karl, T., Judmaier, H., Hansel, A., Jordan, A., Lindinger, W., and Crutzen, P. J: Acetone, methanol, and other partially oxidized volatile organic emissions from dead plant matter by abiological processes: significance for atmospheric $\mathrm{HO}_{\mathrm{x}}$ chemistry, Global Biogeochem. Cy., 13, 9-17, 1999.

Warneke, C., van der Veen, C., Luxembourg, S., de Gouw, J. A, and Kok, A.: Measurements of benzene and toluene in ambient air using proton-transfer-reaction mass spectrometry:

\section{ACPD}

9, 81-134, 2009

VOC concentrations: annual cycle in boreal forest

T. M. Ruuskanen et al.

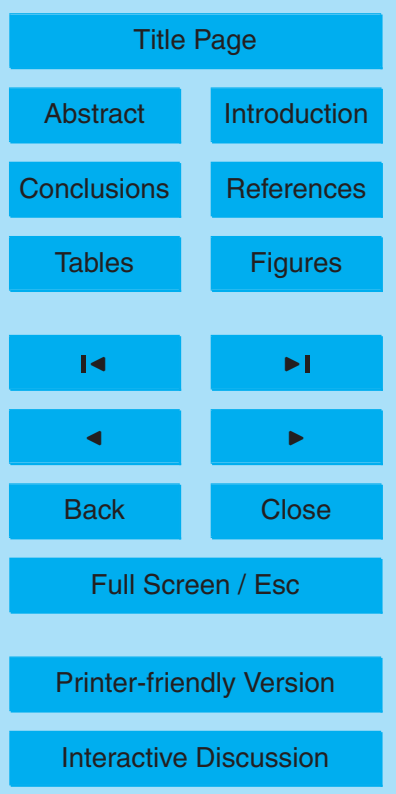


Calibration, humidity dependence, and field intercomparison, Int. J. Mass Spectrom., 207, 167-182, 2001a.

Warneke, C., Holzinger, R., Hansel, A., Jordan, A., Lindinger, W., Pöschl, U., Williams, J., Hoor, P., Fisher, H., Crutzen, P. J., Sheeren, H. A., and Lelieveld, J.: Isoprene and its oxidation products methyl vinyl ketone, methacrolein, and isoprene related peroxides mesaured online over the tropical rain forest of Surinam in March 1998, J. Atmos. Chem., 38, 167-185, 2001b.

Warneke, C., Luxembourg, S. L, de Gouw, J. A, Rinne, H. J. I, Guenther, A. B, and Fall, R.: Disjunct eddy covariance measurements of oxygenated volatile organic compounds fluxes from an alfalfa field before and after cutting, J. Geophys. Res., 107(D8), 4067, doi:10.1029/2001JD000594, 2002.

Warneke, C., De Gouw, J. A, Kuster, W. C, Goldan, P. D, and Fall, R.: Validation of atmospheric VOC measurements by proton-transfer-reaction mass spectrometry using a gaschromatographic preseparation method, Environ. Sci. Technol., 37, 2494-2501, 2003.

\section{ACPD}

9, 81-134, 2009

VOC concentrations: annual cycle in boreal forest

T. M. Ruuskanen et al.

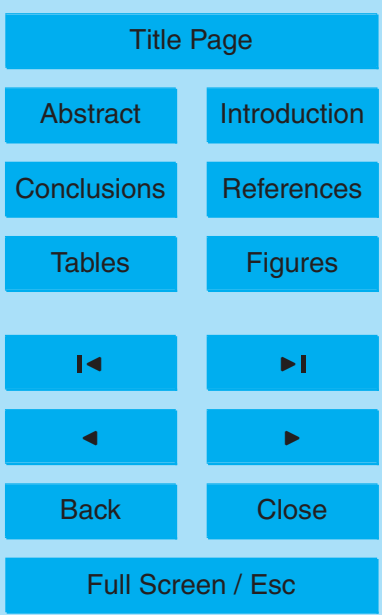

Printer-friendly Version

Interactive Discussion 


\section{ACPD}

9, 81-134, 2009

VOC concentrations: annual cycle in boreal forest

Table 1. Proportions of different land use categories in $40 \times 40 \mathrm{~km}^{2}$ area around SMEAR II station according to Haapanala et al. (2007).

\begin{tabular}{lr}
\hline Land use type & Proportion [\%] \\
\hline Built areas & 0.3 \\
Wetlands & 0.7 \\
Clear cut & 1.7 \\
Deciduous forest & 2.0 \\
Open land & 2.9 \\
Agriculture & 10.2 \\
Water bodies & 13.0 \\
Mixed forest & 20.9 \\
Pine dominated forest & 22.7 \\
Spruce dominated forest & 25.5 \\
\hline
\end{tabular}

Title Page

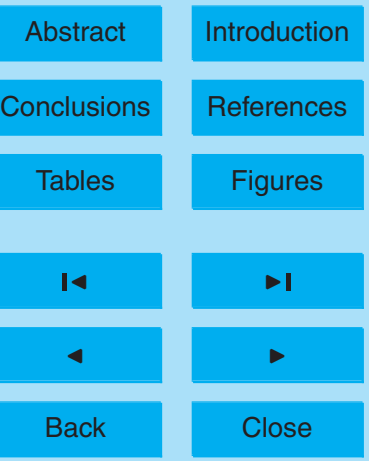

Full Screen / Esc

Printer-friendly Version

Interactive Discussion 
Table 2. Measured masses, compounds used in calibrations and info on compounds (PTR-MS review by de Gouw and Warneke, 2007).

\section{ACPD}

9, 81-134, 2009

\begin{tabular}{|c|c|c|c|}
\hline $\begin{array}{l}\text { measured } \\
\text { mass }\end{array}$ & $\begin{array}{l}\text { measured } \\
\text { calibrated } \\
\text { compound }\end{array}$ & $\begin{array}{l}\text { or other possible } \\
\text { compounds }\end{array}$ & take notice \\
\hline 21 & $\mathrm{H}_{3}^{18} \mathrm{O}^{+}$ & & primary ion \\
\hline 32 & $\mathrm{O}_{2}^{+}$ & & produced in ion source \\
\hline 33 & $\begin{array}{l}\text { methanol } \\
\left(\mathrm{CH}_{3} \mathrm{OH}\right)\end{array}$ & $\mathrm{O}^{16} \mathrm{O}^{17}$ & $\begin{array}{l}0.079 \% \text { of } \mathrm{M} 32, \mathrm{O}_{2}^{+} \text {signal, } \\
\text { reduced }\end{array}$ \\
\hline 39 & $\mathrm{H}_{3} \mathrm{O}\left(\mathrm{H}_{2} \mathrm{O}\right)$ & & water cluster \\
\hline 42 & $\begin{array}{l}\text { acetonitrile } \\
\left(\mathrm{C}_{2} \mathrm{H}_{3} \mathrm{~N}\right)\end{array}$ & & measured since 23.3.2007 \\
\hline 45 & $\begin{array}{l}\text { acetaldehyde } \\
\left(\mathrm{C}_{2} \mathrm{H}_{4} \mathrm{O}\right)\end{array}$ & & \\
\hline 59 & $\begin{array}{l}\text { acetone } \\
\left(\mathrm{C}_{3} \mathrm{H}_{6} \mathrm{O}\right)\end{array}$ & $\mathrm{H}_{3} \mathrm{O}\left(\mathrm{H}_{2} \mathrm{O}^{18}\right)_{2}$ & \\
\hline 69 & $\begin{array}{l}\text { isoprene }\left(\mathrm{C}_{5} \mathrm{H}_{8}\right) \\
\text { and } \\
\text { 2-methyl-3- } \\
\text { buten-2-ol } \\
(\mathrm{MBO})\end{array}$ & $\begin{array}{l}\text { other BVOCs, furan } \\
\text { in biomass burning } \\
\text { plume, anthopogenic } \\
\text { VOC }\end{array}$ & \\
\hline 71 & $\begin{array}{l}\text { methyl vinyl } \\
\text { ketone (MVK), } \\
\text { methacrolein } \\
\left(\mathrm{C}_{4} \mathrm{H}_{6} \mathrm{O}\right)\end{array}$ & & \\
\hline 73 & $\begin{array}{l}\text { 2-butanone } \\
\text { (aka MEK) } \\
\left(\mathrm{C}_{4} \mathrm{H}_{8} \mathrm{O}\right)\end{array}$ & & \\
\hline 79 & benzene $\left(\mathrm{C}_{6} \mathrm{H}_{6}\right)$ & & \\
\hline 101 & $\begin{array}{l}\text { hexenal } \\
\left(\mathrm{C}_{6} \mathrm{H}_{12} \mathrm{O}\right)\end{array}$ & cis-3-hexenol & \\
\hline 137 & $\begin{array}{l}\text { monoterpenes/ } \\
\text { a-pinene } \\
\left(\mathrm{C}_{10} \mathrm{H}_{16}\right)\end{array}$ & other BVOCs? & \\
\hline
\end{tabular}

VOC concentrations: annual cycle in boreal forest

T. M. Ruuskanen et al.

Title Page

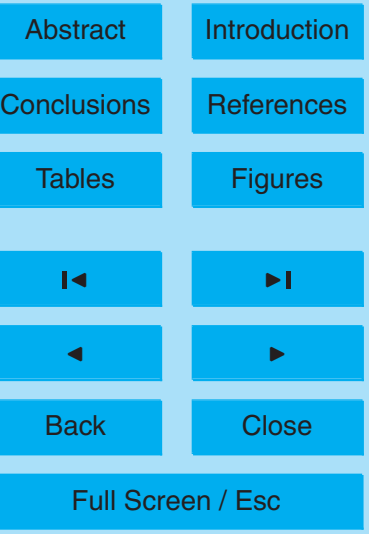

Printer-friendly Version

Interactive Discussion 


\section{ACPD}

9, 81-134, 2009

VOC concentrations: annual cycle in boreal forest

T. M. Ruuskanen et al.

Table 3. Median values of VOCs for total measurement period, summers (June-August), winter (December-February), spring (March-May). Fall is not presented, due to instrument breakdowns from October to beginning of December 2006.

\begin{tabular}{|c|c|c|c|c|c|c|c|c|c|c|c|}
\hline $\begin{array}{l}\text { compound } \\
\text { (mass) }\end{array}$ & $\begin{array}{c}\text { methanol } \\
(33) \\
{[\mathrm{ppbv}]}\end{array}$ & $\begin{array}{c}\text { acetonitrile } \\
(42) \\
\text { [ppbv] }\end{array}$ & $\begin{array}{c}\text { acetaldehyde } \\
(45) \\
\text { [ppbv] }\end{array}$ & $\begin{array}{c}\text { acetone } \\
(59) \\
{[\mathrm{ppbv}]}\end{array}$ & $\begin{array}{c}\text { isoprene-MBO } \\
(69) \\
{[\mathrm{ppbv}]}\end{array}$ & $\begin{array}{c}\text { MACR, MVK } \\
(71) \\
\text { [ppbv] }\end{array}$ & $\begin{array}{c}\text { MEK } \\
(73) \\
{[\mathrm{ppbv}]}\end{array}$ & $\begin{array}{c}\text { benzene } \\
(79) \\
{[\mathrm{ppbv}]}\end{array}$ & $\begin{array}{c}\text { monoterpene } \\
(81) \\
{[\mathrm{ppbv}]}\end{array}$ & $\begin{array}{c}\text { hexanal, } \\
\text { cis-3-hexenol (101) } \\
\text { [ppbv] }\end{array}$ & $\begin{array}{c}\text { monoterpene } \\
(137) \\
\text { [ppbv] }\end{array}$ \\
\hline total & 1.06 & 0.04 & 0.24 & 0.91 & 0.09 & 0.09 & 0.09 & 0.08 & 0.18 & 1.00 & 0.15 \\
\hline summer 06 & 3.00 & na & 0.39 & 2.05 & 0.17 & 0.16 & 0.17 & 0.07 & 0.37 & 0.75 & 0.34 \\
\hline winter 06 & 0.22 & na & 0.16 & 0.33 & 0.05 & 0.07 & 0.06 & 0.14 & 0.09 & 1.22 & 0.05 \\
\hline spring 07 & 0.74 & 0.04 & 0.22 & 0.65 & 0.05 & 0.07 & 0.04 & 0.09 & 0.11 & 1.44 & 0.08 \\
\hline summer 07 & 1.90 & 0.05 & 0.25 & 1.35 & 0.14 & 0.12 & 0.05 & 0.04 & 0.31 & 0.68 & 0.29 \\
\hline
\end{tabular}

Title Page

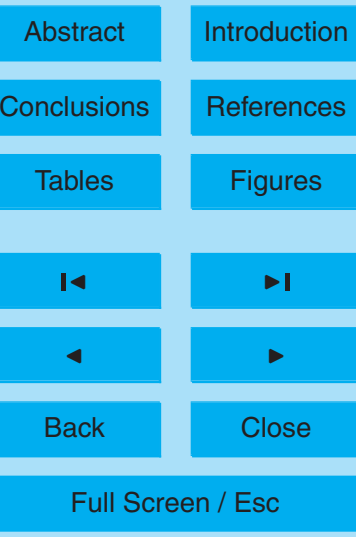

Printer-friendly Version

Interactive Discussion 


\section{ACPD}

9, 81-134, 2009

Table A1. See Appendix A.

\begin{tabular}{lllllll}
\hline $\begin{array}{l}\text { compound } \\
\text { mass }\end{array}$ & time & $\begin{array}{l}\text { average } \\
\text { ppbv }\end{array}$ & $\begin{array}{l}\text { median } \\
\text { ppbv }\end{array}$ & $\begin{array}{l}5 \% \\
\text { ppbv }\end{array}$ & $\begin{array}{l}95 \% \\
\text { ppbv }\end{array}$ & $\begin{array}{l}\mathrm{N} \\
\text { hours }\end{array}$ \\
\hline methanol & total & 1.59 & 1.06 & 0.17 & 4.90 & 3315 \\
33 & June & 4.05 & 3.34 & 1.97 & 7.32 & 171 \\
& July & 3.16 & 2.91 & 1.45 & 5.81 & 327 \\
& August & 2.94 & 2.88 & 1.20 & 5.05 & 307 \\
& September & 1.25 & 1.13 & 0.60 & 2.44 & 220 \\
& October & na & na & na & na & 0 \\
& November & 0.30 & 0.30 & 0.24 & 0.37 & 11 \\
& December & 0.24 & 0.22 & 0.15 & 0.37 & 324 \\
& January & 0.23 & 0.21 & 0.11 & 0.45 & 358 \\
& February & 0.41 & 0.33 & 0.13 & 0.74 & 57 \\
& March & 0.54 & 0.35 & 0.18 & 1.60 & 281 \\
& April & 0.77 & 0.66 & 0.31 & 1.74 & 234 \\
& May & 1.58 & 1.45 & 0.76 & 2.79 & 229 \\
& June & 3.62 & 3.25 & 1.45 & 6.90 & 188 \\
& July & 1.69 & 1.34 & 0.65 & 3.86 & 206 \\
& August & 1.70 & 1.45 & 0.58 & 3.66 & 204 \\
& September & 0.74 & 0.68 & 0.40 & 1.27 & 184 \\
\hline
\end{tabular}

VOC concentrations: annual cycle in boreal forest

T. M. Ruuskanen et al.

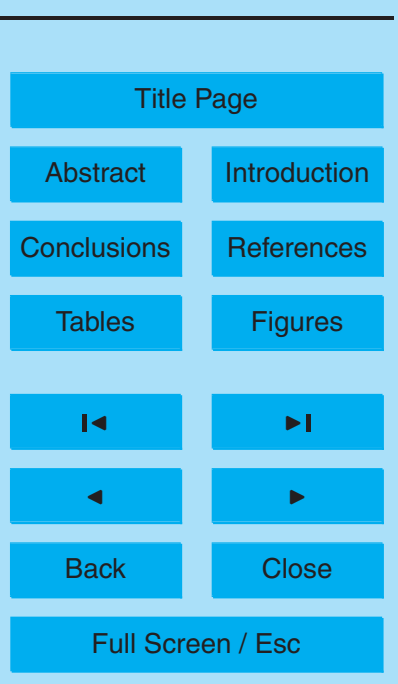

Printer-friendly Version

Interactive Discussion 
Table A1. Continued.

\begin{tabular}{lllllll}
\hline $\begin{array}{l}\text { compound } \\
\text { mass }\end{array}$ & time & $\begin{array}{l}\text { average } \\
\text { ppbv }\end{array}$ & $\begin{array}{l}\text { median } \\
\text { ppbv }\end{array}$ & $\begin{array}{l}5 \% \\
\text { ppbv }\end{array}$ & $\begin{array}{l}95 \% \\
\text { ppbv }\end{array}$ & $\begin{array}{l}\mathrm{N} \\
\text { hours }\end{array}$ \\
\hline acetonitrile & total & 0.05 & 0.04 & 0.02 & 0.09 & 3315 \\
42 & March & 0.08 & 0.08 & 0.02 & 0.13 & 60 \\
& April & 0.03 & 0.03 & 0.02 & 0.06 & 234 \\
& May & 0.04 & 0.04 & 0.02 & 0.07 & 229 \\
& June & 0.07 & 0.06 & 0.04 & 0.10 & 188 \\
& July & 0.04 & 0.04 & 0.02 & 0.07 & 206 \\
acetaldehyde & August & 0.05 & 0.05 & 0.03 & 0.08 & 204 \\
45 & September & 0.03 & 0.03 & 0.02 & 0.05 & 184 \\
& total & 0.29 & 0.24 & 0.12 & 0.65 & 3315 \\
& June & 0.47 & 0.41 & 0.24 & 0.84 & 171 \\
& July & 0.39 & 0.35 & 0.14 & 0.73 & 327 \\
& August & 0.50 & 0.43 & 0.19 & 0.95 & 307 \\
& September & 0.27 & 0.25 & 0.13 & 0.49 & 220 \\
& October & na & na & na & na & 0 \\
& November & 0.26 & 0.25 & 0.20 & 0.34 & 11 \\
& December & 0.16 & 0.15 & 0.11 & 0.26 & 324 \\
& January & 0.18 & 0.16 & 0.10 & 0.30 & 358 \\
& February & 0.32 & 0.30 & 0.19 & 0.51 & 57 \\
& March & 0.26 & 0.23 & 0.13 & 0.46 & 281 \\
& April & 0.21 & 0.19 & 0.12 & 0.39 & 234 \\
& May & 0.27 & 0.26 & 0.15 & 0.44 & 229 \\
& June & 0.40 & 0.36 & 0.20 & 0.69 & 188 \\
& July & 0.22 & 0.20 & 0.11 & 0.39 & 206 \\
& August & 0.27 & 0.24 & 0.12 & 0.50 & 204 \\
& September & 0.19 & 0.18 & 0.10 & 0.32 & 184 \\
\hline \multirow{4}{*}{4} & & & & & \\
& & & & & \\
& & & & &
\end{tabular}

VOC concentrations: annual cycle in boreal forest

T. M. Ruuskanen et al.

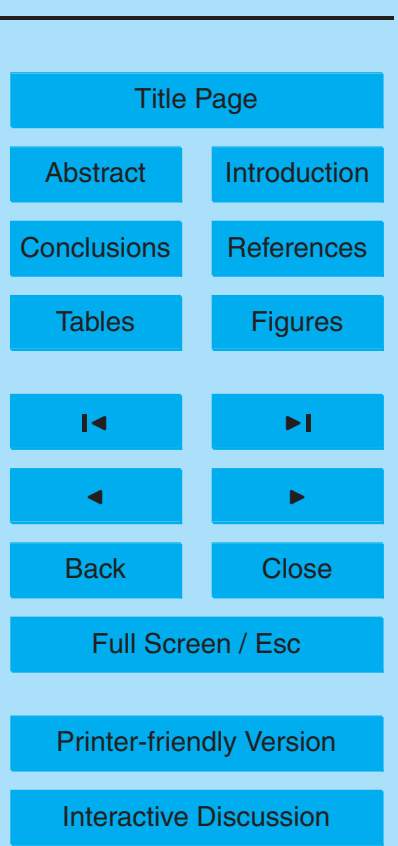




\section{ACPD}

9, 81-134, 2009

Table A1. Continued.

\begin{tabular}{lllllll}
\hline $\begin{array}{l}\text { compound } \\
\text { mass }\end{array}$ & time & $\begin{array}{l}\text { average } \\
\text { ppbv }\end{array}$ & $\begin{array}{l}\text { median } \\
\text { ppbv }\end{array}$ & $\begin{array}{l}5 \% \\
\text { ppbv }\end{array}$ & $\begin{array}{l}95 \% \\
\text { ppbv }\end{array}$ & $\begin{array}{l}\mathrm{N} \\
\text { hours }\end{array}$ \\
\hline acetone & total & 1.17 & 0.91 & 0.27 & 2.90 & 3315 \\
59 & June & 2.17 & 1.96 & 1.13 & 3.66 & 171 \\
& July & 1.93 & 1.81 & 0.67 & 3.77 & 327 \\
& August & 2.44 & 2.34 & 1.23 & 4.14 & 307 \\
& September & 1.28 & 1.18 & 0.73 & 2.11 & 220 \\
& October & 0.53 & 0.52 & 0.47 & 0.62 & 0 \\
& November & na & na & na & na & 11 \\
& December & 0.38 & 0.37 & 0.27 & 0.54 & 324 \\
& January & 0.31 & 0.30 & 0.22 & 0.44 & 358 \\
& February & 0.39 & 0.37 & 0.25 & 0.58 & 57 \\
& March & 0.62 & 0.49 & 0.31 & 1.46 & 281 \\
& April & 0.67 & 0.58 & 0.40 & 1.31 & 234 \\
& May & 1.02 & 0.99 & 0.59 & 1.58 & 229 \\
& June & 1.66 & 1.62 & 0.87 & 2.61 & 188 \\
& July & 1.28 & 1.22 & 0.65 & 2.26 & 206 \\
& August & 1.50 & 1.44 & 0.73 & 2.57 & 204 \\
& September & 0.73 & 0.73 & 0.47 & 1.02 & 184 \\
\hline
\end{tabular}

VOC concentrations: annual cycle in boreal forest

T. M. Ruuskanen et al.

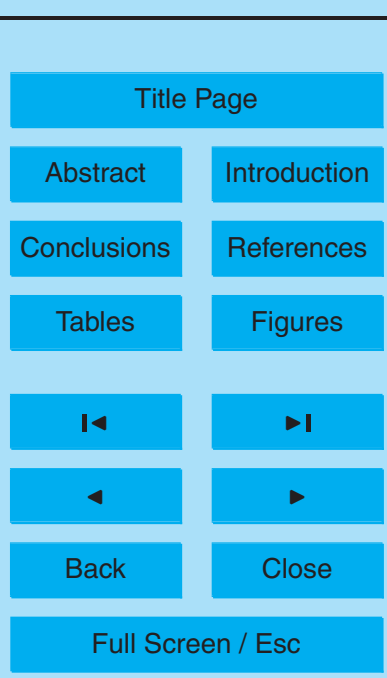

Printer-friendly Version

Interactive Discussion 


\section{ACPD}

9, 81-134, 2009

Table A1. Continued.

\begin{tabular}{|c|c|c|c|c|c|c|}
\hline $\begin{array}{l}\text { compound } \\
\text { mass }\end{array}$ & time & $\begin{array}{l}\text { average } \\
\text { ppbv }\end{array}$ & $\begin{array}{l}\text { median } \\
\text { ppbv }\end{array}$ & $\begin{array}{l}5 \% \\
\text { ppbv }\end{array}$ & $\begin{array}{l}95 \% \\
\text { ppbv }\end{array}$ & $\begin{array}{l}\mathrm{N} \\
\text { hours }\end{array}$ \\
\hline isoprene-MBO & total & 0.11 & 0.09 & 0.03 & 0.28 & 3315 \\
\hline \multirow[t]{16}{*}{69} & June & 0.15 & 0.14 & 0.06 & 0.28 & 171 \\
\hline & July & 0.20 & 0.19 & 0.07 & 0.34 & 327 \\
\hline & August & 0.21 & 0.19 & 0.07 & 0.40 & 307 \\
\hline & September & 0.14 & 0.13 & 0.08 & 0.20 & 220 \\
\hline & October & na & na & na & na & 0 \\
\hline & November & 0.09 & 0.09 & 0.06 & 0.13 & 11 \\
\hline & December & 0.06 & 0.05 & 0.03 & 0.09 & 324 \\
\hline & January & 0.05 & 0.05 & 0.03 & 0.09 & 358 \\
\hline & February & 0.05 & 0.05 & 0.03 & 0.12 & 57 \\
\hline & March & 0.06 & 0.05 & 0.03 & 0.09 & 281 \\
\hline & April & 0.05 & 0.05 & 0.02 & 0.10 & 234 \\
\hline & May & 0.07 & 0.07 & 0.04 & 0.14 & 229 \\
\hline & June & 0.17 & 0.16 & 0.07 & 0.30 & 188 \\
\hline & July & 0.14 & 0.13 & 0.06 & 0.27 & 206 \\
\hline & August & 0.17 & 0.15 & 0.08 & 0.33 & 204 \\
\hline & September & 0.09 & 0.09 & 0.05 & 0.13 & 184 \\
\hline
\end{tabular}

VOC concentrations: annual cycle in boreal forest

T. M. Ruuskanen et al.

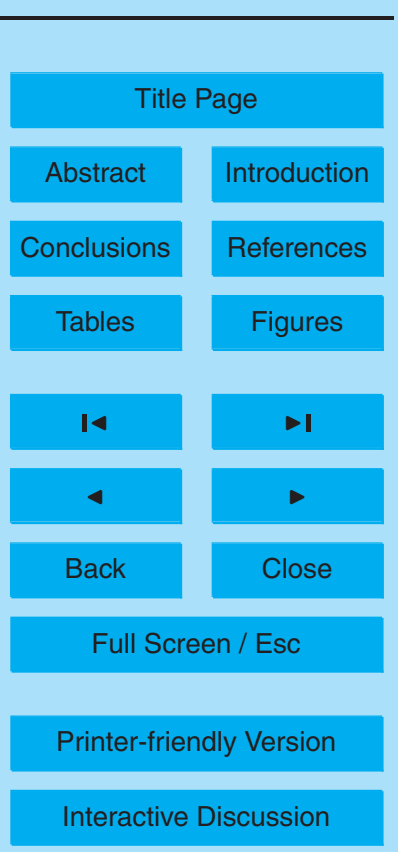




\section{ACPD}

9, 81-134, 2009

Table A1. Continued.

\begin{tabular}{lllllll}
\hline $\begin{array}{l}\text { compound } \\
\text { mass }\end{array}$ & time & $\begin{array}{l}\text { average } \\
\text { ppbv }\end{array}$ & $\begin{array}{l}\text { median } \\
\text { ppbv }\end{array}$ & $\begin{array}{l}5 \% \\
\text { ppbv }\end{array}$ & $\begin{array}{l}95 \% \\
\text { ppbv }\end{array}$ & $\begin{array}{l}\mathrm{N} \\
\text { hours }\end{array}$ \\
\hline MACR. MVK & total & 0.11 & 0.09 & 0.04 & 0.27 & 3315 \\
71 & June & 0.19 & 0.19 & 0.05 & 0.34 & 171 \\
& July & 0.16 & 0.14 & 0.04 & 0.32 & 327 \\
& August & 0.19 & 0.16 & 0.05 & 0.39 & 307 \\
& September & 0.09 & 0.08 & 0.03 & 0.15 & 220 \\
& October & na & na & na & na & 0 \\
& November & 0.15 & 0.14 & 0.13 & 0.23 & 11 \\
& December & 0.08 & 0.07 & 0.04 & 0.15 & 324 \\
& January & 0.06 & 0.06 & 0.04 & 0.11 & 358 \\
& February & 0.08 & 0.07 & 0.04 & 0.17 & 57 \\
& March & 0.09 & 0.08 & 0.04 & 0.17 & 281 \\
& April & 0.06 & 0.05 & 0.03 & 0.13 & 234 \\
& May & 0.07 & 0.06 & 0.04 & 0.11 & 229 \\
& June & 0.12 & 0.11 & 0.05 & 0.21 & 188 \\
& July & 0.10 & 0.09 & 0.05 & 0.22 & 206 \\
& August & 0.17 & 0.15 & 0.08 & 0.31 & 204 \\
& September & 0.12 & 0.12 & 0.05 & 0.16 & 184 \\
\hline
\end{tabular}

VOC concentrations: annual cycle in boreal forest

T. M. Ruuskanen et al.

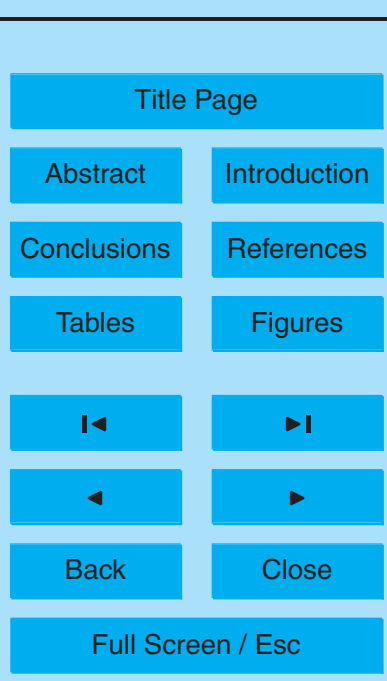

Printer-friendly Version

Interactive Discussion 


\section{ACPD}

9, 81-134, 2009

Table A1. Continued.

\begin{tabular}{lllllll}
\hline $\begin{array}{l}\text { compound } \\
\text { mass }\end{array}$ & time & $\begin{array}{l}\text { average } \\
\text { ppbv }\end{array}$ & $\begin{array}{l}\text { median } \\
\text { ppbv }\end{array}$ & $\begin{array}{l}5 \% \\
\text { ppbv }\end{array}$ & $\begin{array}{l}95 \% \\
\text { ppbv }\end{array}$ & $\begin{array}{l}\mathrm{N} \\
\text { hours }\end{array}$ \\
\hline MEK & total & 0.12 & 0.09 & 0.04 & 0.31 & 3315 \\
73 & June & 0.16 & 0.14 & 0.05 & 0.31 & 171 \\
& July & 0.17 & 0.14 & 0.04 & 0.37 & 327 \\
& August & 0.25 & 0.22 & 0.09 & 0.49 & 307 \\
& September & 0.13 & 0.13 & 0.03 & 0.28 & 220 \\
& October & na & na & na & na & 0 \\
& November & 0.08 & 0.08 & 0.06 & 0.09 & 11 \\
& December & 0.06 & 0.06 & 0.04 & 0.09 & 324 \\
& January & 0.06 & 0.05 & 0.03 & 0.11 & 358 \\
& February & 0.08 & 0.08 & 0.05 & 0.13 & 57 \\
& March & 0.10 & 0.09 & 0.05 & 0.22 & 281 \\
& April & 0.09 & 0.08 & 0.05 & 0.14 & 234 \\
& May & 0.10 & 0.10 & 0.05 & 0.18 & 229 \\
& June & 0.12 & 0.12 & 0.05 & 0.23 & 188 \\
& July & 0.18 & 0.15 & 0.03 & 0.37 & 206 \\
& August & 0.17 & 0.15 & 0.05 & 0.33 & 204 \\
& September & 0.07 & 0.07 & 0.04 & 0.11 & 184 \\
\hline
\end{tabular}

VOC concentrations: annual cycle in boreal forest

T. M. Ruuskanen et al.

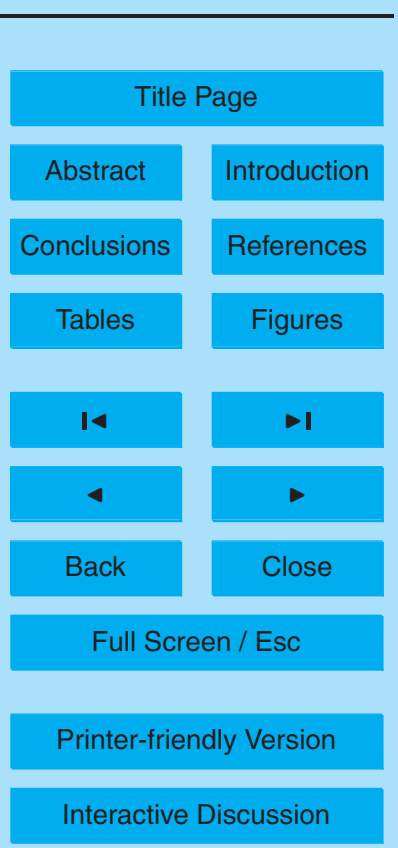




\section{ACPD}

9, 81-134, 2009

Table A1. Continued.

\begin{tabular}{lllllll}
\hline $\begin{array}{l}\text { compound } \\
\text { mass }\end{array}$ & time & $\begin{array}{l}\text { average } \\
\text { ppbv }\end{array}$ & $\begin{array}{l}\text { median } \\
\text { ppbv }\end{array}$ & $\begin{array}{l}5 \% \\
\text { ppbv }\end{array}$ & $\begin{array}{l}95 \% \\
\text { ppbv }\end{array}$ & $\begin{array}{l}\mathrm{N} \\
\text { hours }\end{array}$ \\
\hline benzene & total & 0.10 & 0.08 & 0.02 & 0.23 & 3315 \\
79 & June & 0.06 & 0.06 & 0.02 & 0.12 & 171 \\
& July & 0.06 & 0.05 & 0.01 & 0.16 & 327 \\
& August & 0.11 & 0.09 & 0.04 & 0.29 & 307 \\
& September & 0.07 & 0.06 & 0.02 & 0.15 & 220 \\
& October & na & na & na & na & 0 \\
& November & 0.20 & 0.12 & 0.10 & 0.46 & 11 \\
& December & 0.13 & 0.11 & 0.09 & 0.21 & 324 \\
& January & 0.17 & 0.17 & 0.11 & 0.27 & 358 \\
& February & 0.20 & 0.19 & 0.14 & 0.32 & 57 \\
& March & 0.18 & 0.16 & 0.10 & 0.37 & 281 \\
& April & 0.08 & 0.08 & 0.06 & 0.11 & 234 \\
& May & 0.06 & 0.06 & 0.03 & 0.09 & 229 \\
& June & 0.04 & 0.04 & 0.02 & 0.08 & 188 \\
& July & 0.05 & 0.04 & 0.02 & 0.09 & 206 \\
& August & 0.06 & 0.05 & 0.02 & 0.12 & 204 \\
& September & 0.04 & 0.04 & 0.02 & 0.07 & 184 \\
\hline
\end{tabular}

VOC concentrations: annual cycle in boreal forest

T. M. Ruuskanen et al.

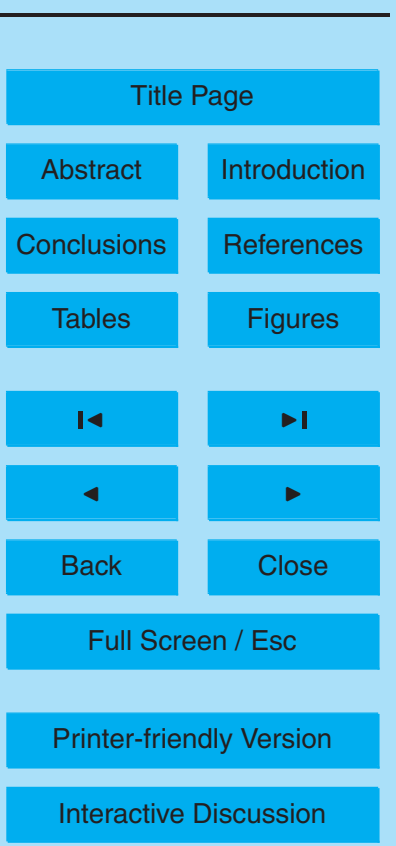




\section{ACPD}

9, 81-134, 2009

Table A1. Continued.

\begin{tabular}{lllllll}
\hline $\begin{array}{l}\text { compound } \\
\text { mass }\end{array}$ & time & $\begin{array}{l}\text { average } \\
\text { ppbv }\end{array}$ & $\begin{array}{l}\text { median } \\
\text { ppbv }\end{array}$ & $\begin{array}{l}5 \% \\
\text { ppbv }\end{array}$ & $\begin{array}{l}95 \% \\
\text { ppbv }\end{array}$ & $\begin{array}{l}\mathrm{N} \\
\text { hours }\end{array}$ \\
\hline monoterpenes & total & 0.26 & 0.18 & 0.06 & 0.66 & 3315 \\
81 & June & 0.40 & 0.32 & 0.16 & 0.86 & 171 \\
& July & 0.38 & 0.35 & 0.12 & 0.71 & 327 \\
& August & 0.48 & 0.42 & 0.24 & 0.93 & 307 \\
& September & 0.25 & 0.25 & 0.13 & 0.39 & 220 \\
& October & na & na & na & na & 0 \\
& November & 0.12 & 0.11 & 0.09 & 0.16 & 11 \\
& December & 0.10 & 0.09 & 0.06 & 0.13 & 324 \\
& January & 0.14 & 0.09 & 0.05 & 0.29 & 358 \\
& February & 0.14 & 0.07 & 0.05 & 0.69 & 57 \\
& March & 0.15 & 0.09 & 0.06 & 0.41 & 281 \\
& April & 0.12 & 0.10 & 0.06 & 0.20 & 234 \\
& May & 0.20 & 0.15 & 0.09 & 0.44 & 229 \\
& June & 0.41 & 0.36 & 0.16 & 0.80 & 188 \\
& July & 0.36 & 0.30 & 0.15 & 0.75 & 206 \\
& August & 0.37 & 0.25 & 0.12 & 1.05 & 204 \\
& September & 0.19 & 0.16 & 0.09 & 0.37 & 184 \\
\hline
\end{tabular}

VOC concentrations: annual cycle in boreal forest

T. M. Ruuskanen et al.

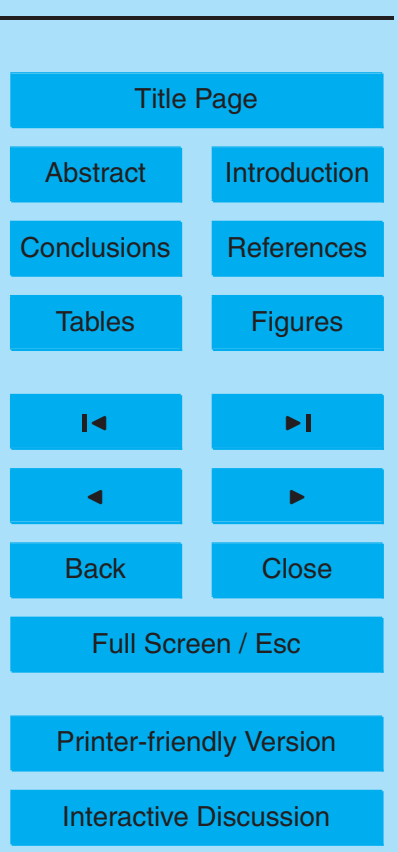




\section{ACPD}

9, 81-134, 2009

Table A1. Continued.

\begin{tabular}{lllllll}
\hline $\begin{array}{l}\text { compound } \\
\text { mass }\end{array}$ & time & $\begin{array}{l}\text { average } \\
\text { ppbv }\end{array}$ & $\begin{array}{l}\text { median } \\
\text { ppbv }\end{array}$ & $\begin{array}{l}5 \% \\
\text { ppbv }\end{array}$ & $\begin{array}{l}95 \% \\
\text { ppbv }\end{array}$ & $\begin{array}{l}\mathrm{N} \\
\text { hours }\end{array}$ \\
\hline hexanal. & total & 1.09 & 1.00 & 0.23 & 2.26 & 3315 \\
cis-3-hexenol & June & 0.79 & 0.65 & 0.25 & 1.72 & 171 \\
101 & July & 0.80 & 0.74 & 0.24 & 1.62 & 327 \\
& August & 1.12 & 0.91 & 0.28 & 2.88 & 307 \\
& September & 0.47 & 0.45 & 0.23 & 0.80 & 220 \\
& October & na & na & na & na & 0 \\
& November & 2.11 & 2.31 & 1.43 & 2.45 & 11 \\
& December & 1.40 & 1.38 & 0.90 & 1.99 & 324 \\
& January & 1.21 & 1.13 & 0.85 & 1.81 & 358 \\
& February & 0.90 & 0.88 & 0.63 & 1.17 & 57 \\
& March & 1.48 & 1.09 & 0.74 & 4.08 & 281 \\
& April & 1.94 & 1.88 & 1.25 & 3.01 & 234 \\
& May & 1.53 & 1.42 & 1.05 & 2.26 & 229 \\
& June & 1.42 & 1.25 & 0.74 & 2.37 & 188 \\
& July & 0.70 & 0.58 & 0.28 & 1.60 & 206 \\
& August & 0.53 & 0.49 & 0.27 & 0.94 & 204 \\
& September & 0.22 & 0.22 & 0.16 & 0.29 & 184 \\
\hline
\end{tabular}

VOC concentrations: annual cycle in boreal forest

T. M. Ruuskanen et al.

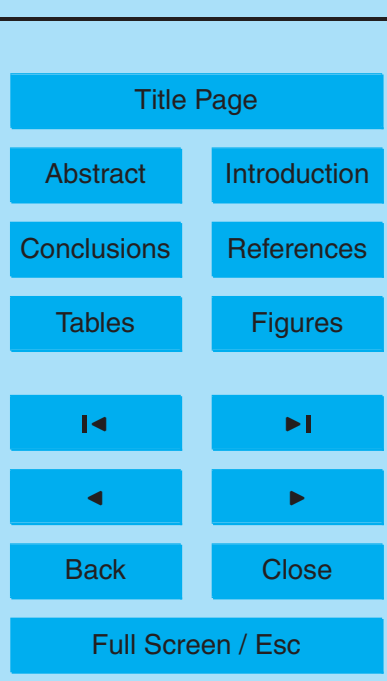

Printer-friendly Version

Interactive Discussion 


\section{ACPD}

9, 81-134, 2009

Table A1. Continued.

\begin{tabular}{|c|c|c|c|c|c|c|}
\hline $\begin{array}{l}\text { compound } \\
\text { mass }\end{array}$ & time & $\begin{array}{l}\text { average } \\
\text { ppbv }\end{array}$ & $\begin{array}{l}\text { median } \\
\text { ppbv }\end{array}$ & $\begin{array}{l}5 \% \\
\text { ppbv }\end{array}$ & $\begin{array}{l}95 \% \\
\text { ppbv }\end{array}$ & $\begin{array}{l}\mathrm{N} \\
\text { hours }\end{array}$ \\
\hline monoterpenes & total & 0.23 & 0.15 & 0.03 & 0.68 & 3315 \\
\hline \multirow[t]{16}{*}{137} & June & 0.38 & 0.33 & 0.13 & 0.91 & 171 \\
\hline & July & 0.35 & 0.32 & 0.07 & 0.70 & 327 \\
\hline & August & 0.45 & 0.37 & 0.18 & 1.01 & 307 \\
\hline & September & 0.18 & 0.17 & 0.06 & 0.36 & 220 \\
\hline & October & na & na & na & na & 0 \\
\hline & November & 0.10 & 0.09 & 0.04 & 0.18 & 11 \\
\hline & December & 0.06 & 0.05 & 0.03 & 0.10 & 324 \\
\hline & January & 0.11 & 0.05 & 0.01 & 0.25 & 358 \\
\hline & February & 0.11 & 0.04 & 0.02 & 0.68 & 57 \\
\hline & March & 0.12 & 0.07 & 0.03 & 0.40 & 281 \\
\hline & April & 0.09 & 0.07 & 0.03 & 0.20 & 234 \\
\hline & May & 0.18 & 0.13 & 0.06 & 0.53 & 229 \\
\hline & June & 0.36 & 0.30 & 0.11 & 0.77 & 188 \\
\hline & July & 0.37 & 0.30 & 0.13 & 0.81 & 206 \\
\hline & August & 0.36 & 0.24 & 0.10 & 0.97 & 204 \\
\hline & September & 0.16 & 0.13 & 0.05 & 0.32 & 184 \\
\hline
\end{tabular}

VOC concentrations: annual cycle in boreal forest

T. M. Ruuskanen et al.

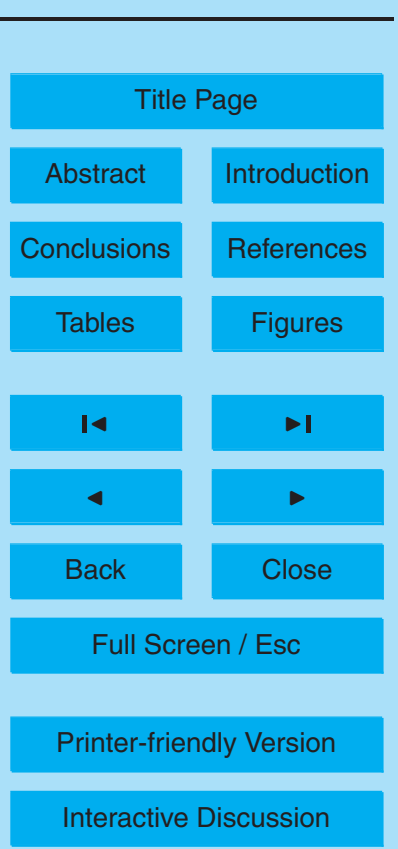




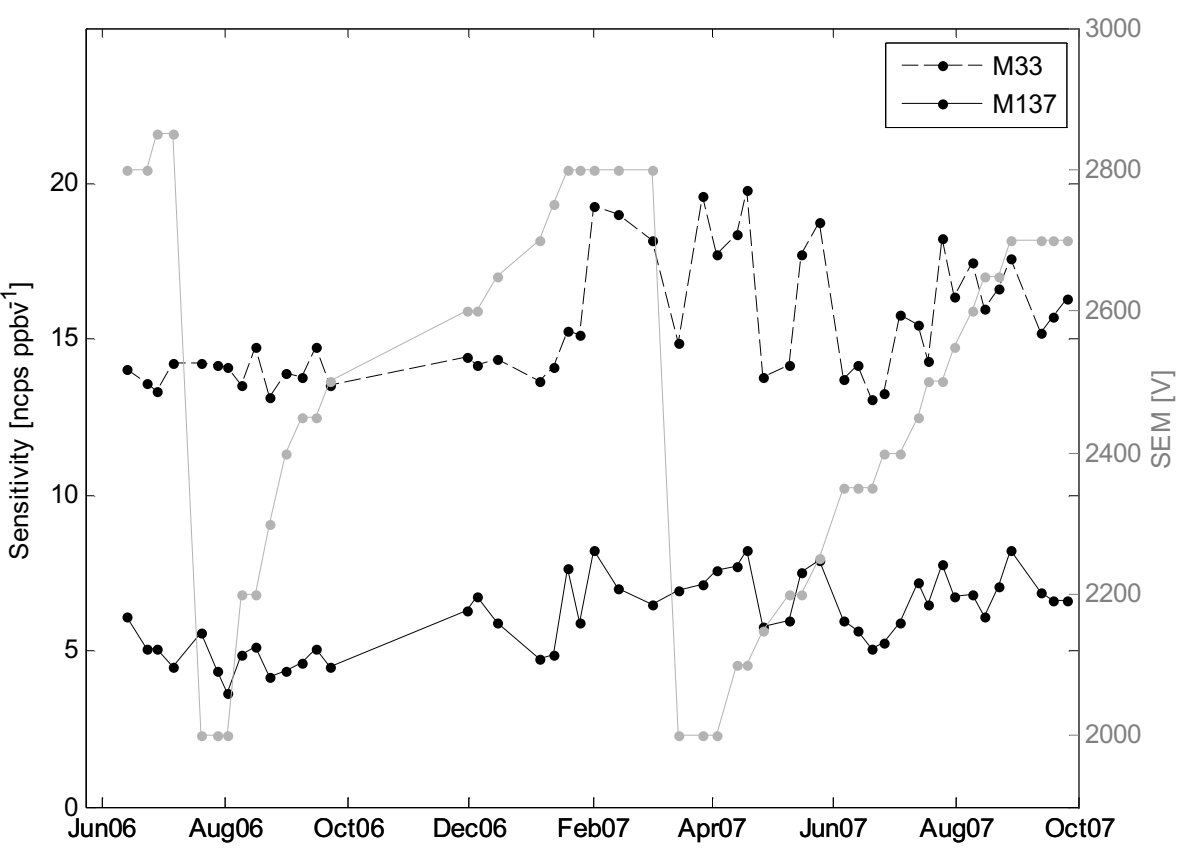

Fig. 1. Sensitivity from calibrations of light compound, methanol at M33, and a heavier compound, monoterpenes at M137, and SEM operation voltage (right axis) during spring 2006 to fall 2007. When SEM was used up we changed a new one (in 19 July 2006 and 15 March 2007), initial operation voltage was $2000 \mathrm{~V}$.
ACPD

9, 81-134, 2009

VOC concentrations: annual cycle in boreal forest

T. M. Ruuskanen et al.

Title Page

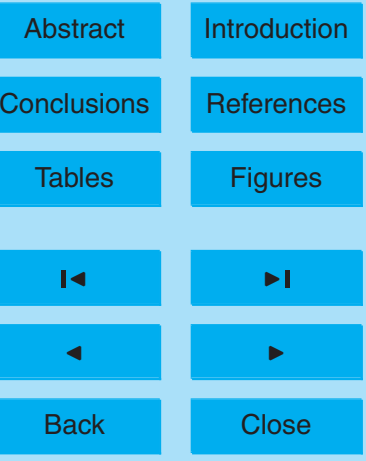

Full Screen / Esc

Printer-friendly Version

Interactive Discussion 


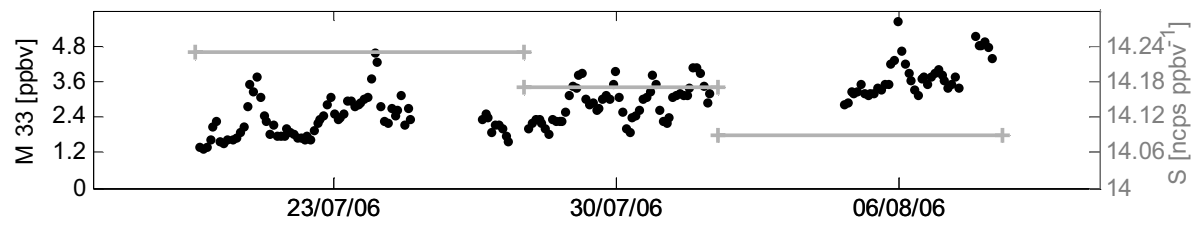

\section{ACPD}

9, 81-134, 2009

VOC concentrations: annual cycle in boreal forest
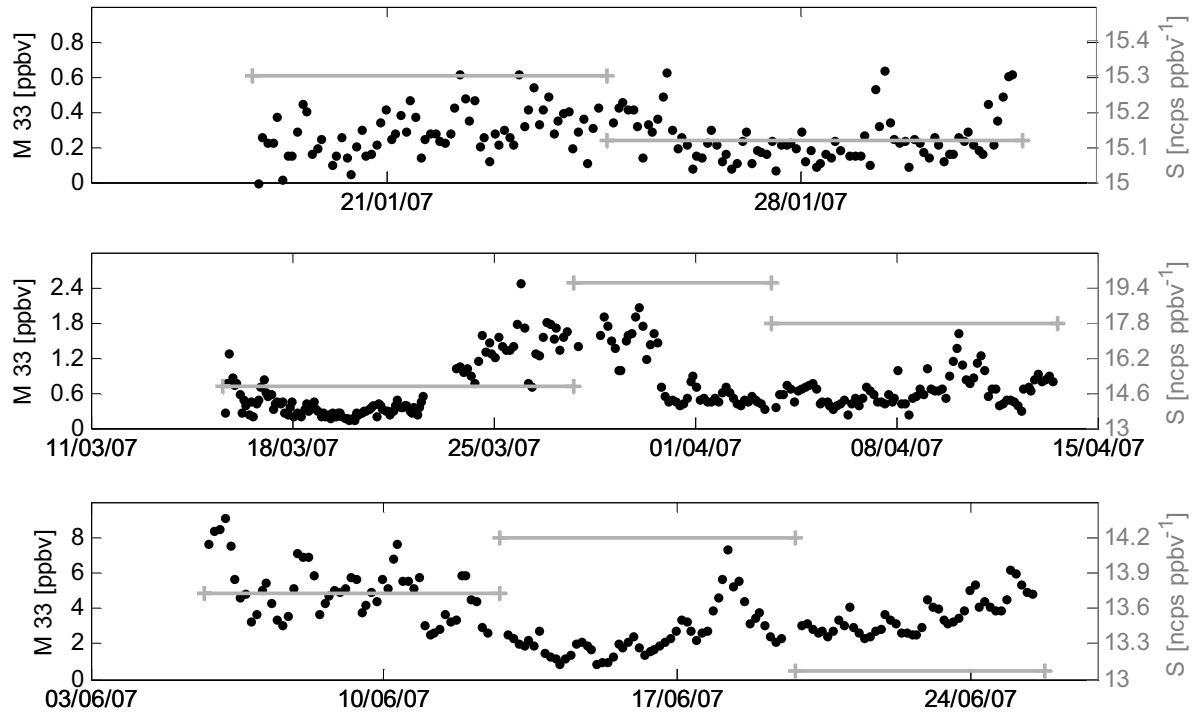

T. M. Ruuskanen et al.

Title Page

Abstract

Introduction

Conclusions

References

Tables

Figures

14

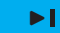

4

Back

Close

Full Screen / Esc

Fig. 2. Measured volume mixing ratio of methanol during four periods of constant SEM operation voltage (Fig. 1) each in separate panel. Sensitivity of methanol (right axis) was determined from regular calibration. Notice that the duration is different for each panel.

Printer-friendly Version

Interactive Discussion

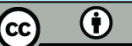




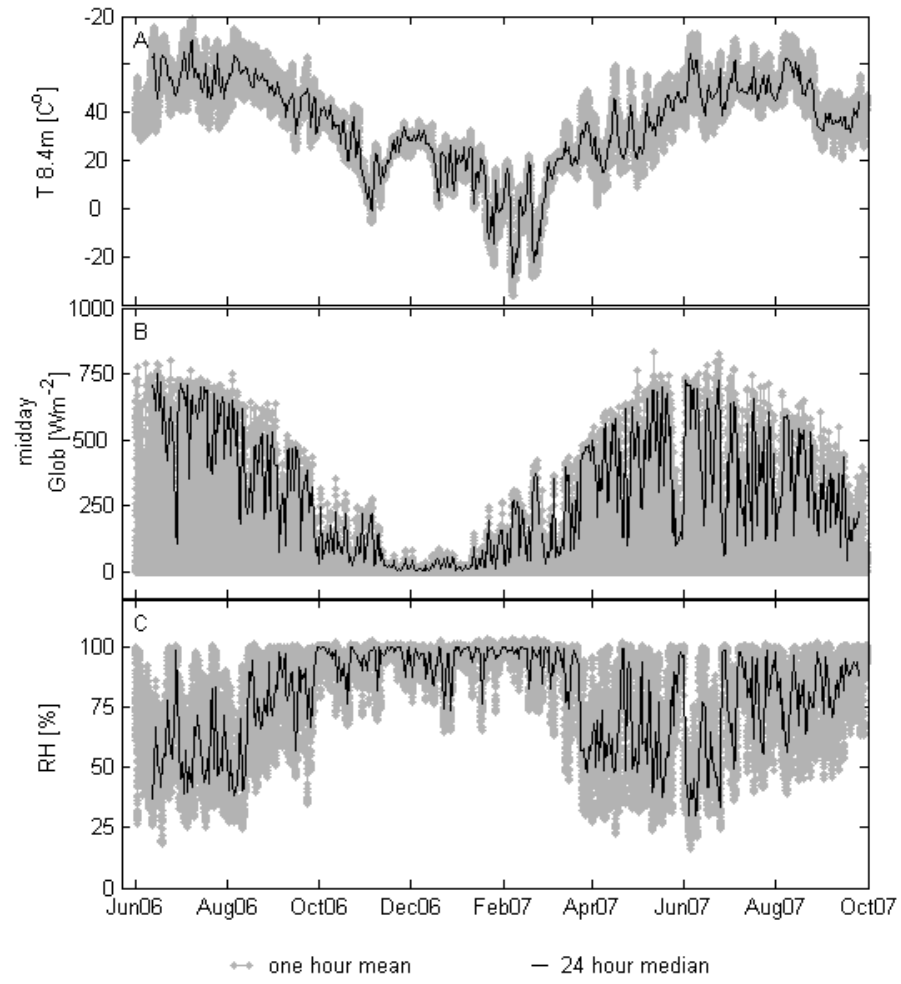

9, 81-134, 2009

VOC concentrations: annual cycle in boreal forest

T. M. Ruuskanen et al.

Title Page

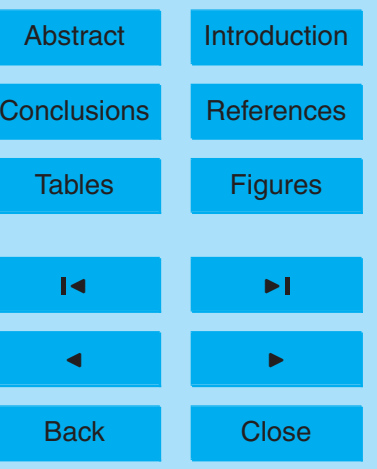

Full Screen / Esc

Fig. 3. Meteorological data during the ambient VOC measurements. Half an hour averages (grey) and temperature and relative humidity $24 \mathrm{~h}$ medians (black) and global radiation midday medians (12:30 UT $\pm 2 \mathrm{~h}$, black).

Printer-friendly Version

Interactive Discussion 


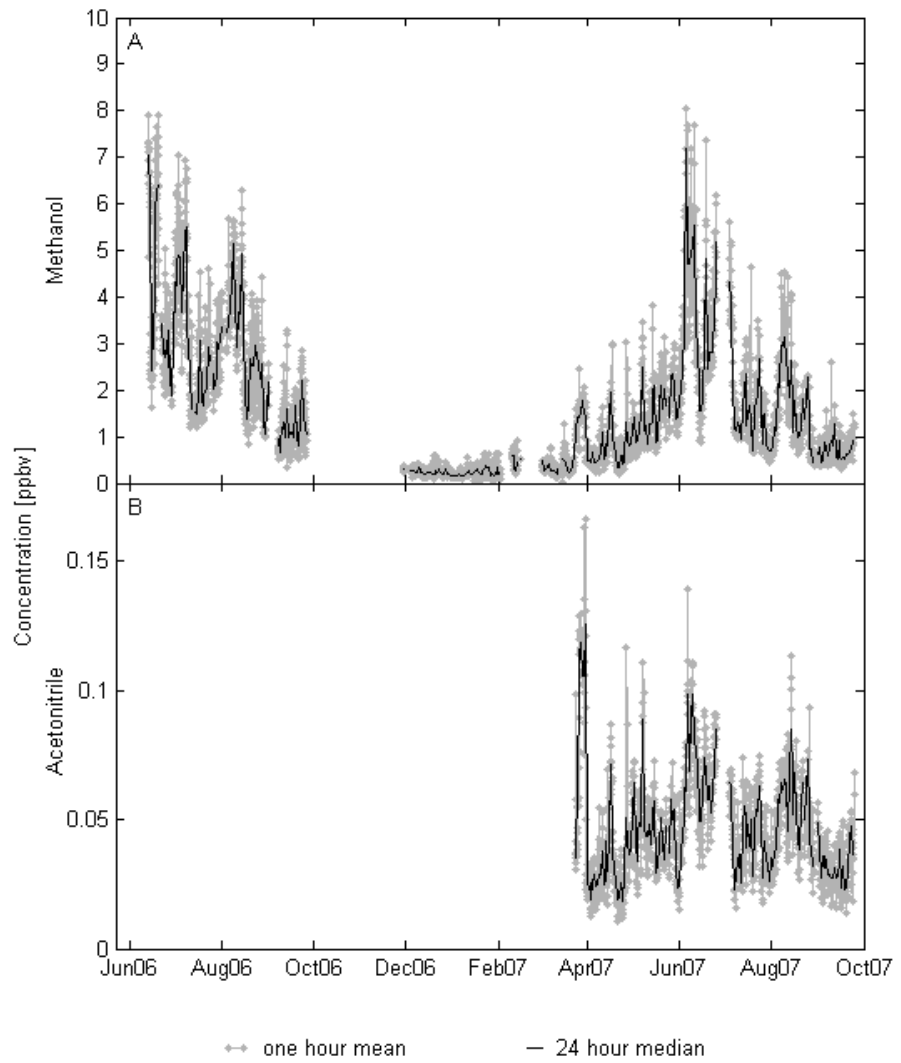

Fig. 4. Ambient methanol (M33) and acetonitrile (M42) volume mixing ratios measured from $14 \mathrm{~m}$ height at SMEAR II station.

\section{ACPD}

9, 81-134, 2009

VOC concentrations: annual cycle in boreal forest

T. M. Ruuskanen et al.

Title Page

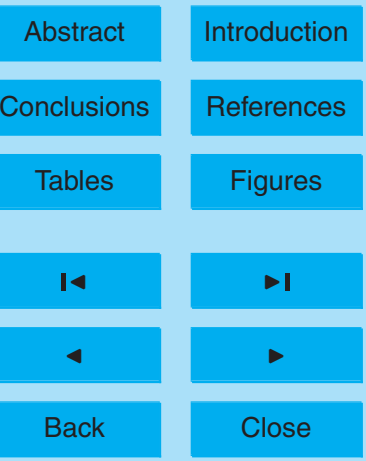

Full Screen / Esc

Printer-friendly Version

Interactive Discussion 


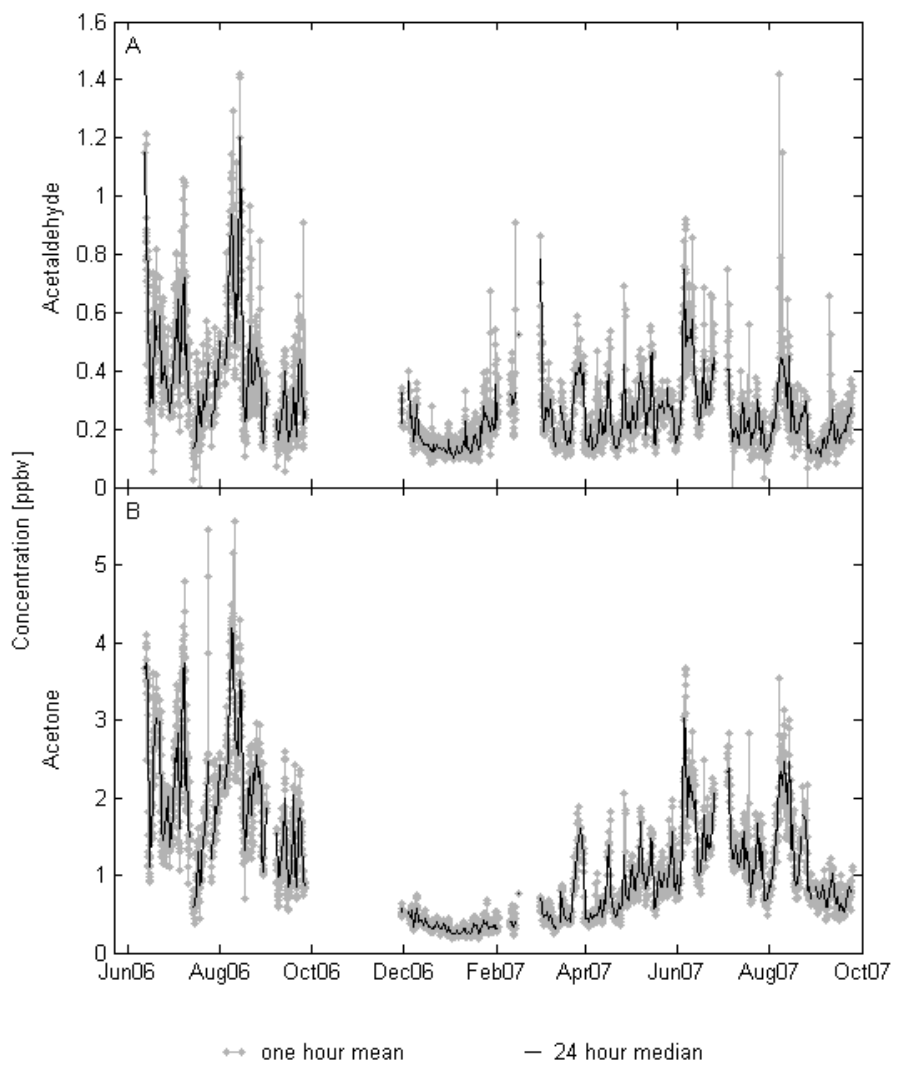

Fig. 5. Ambient acetaldehyde (M45) and acetone (M59) volume mixing ratios measured from $14 \mathrm{~m}$ height at SMEAR II station.

\section{ACPD}

9, 81-134, 2009

VOC concentrations: annual cycle in boreal forest

T. M. Ruuskanen et al.

Title Page

Abstract

Conclusions

Tables

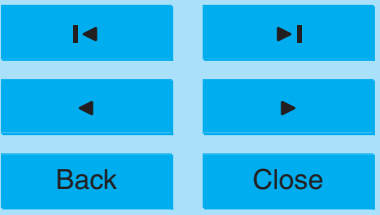

Full Screen / Esc

Printer-friendly Version

Interactive Discussion 


\section{ACPD}

9, 81-134, 2009

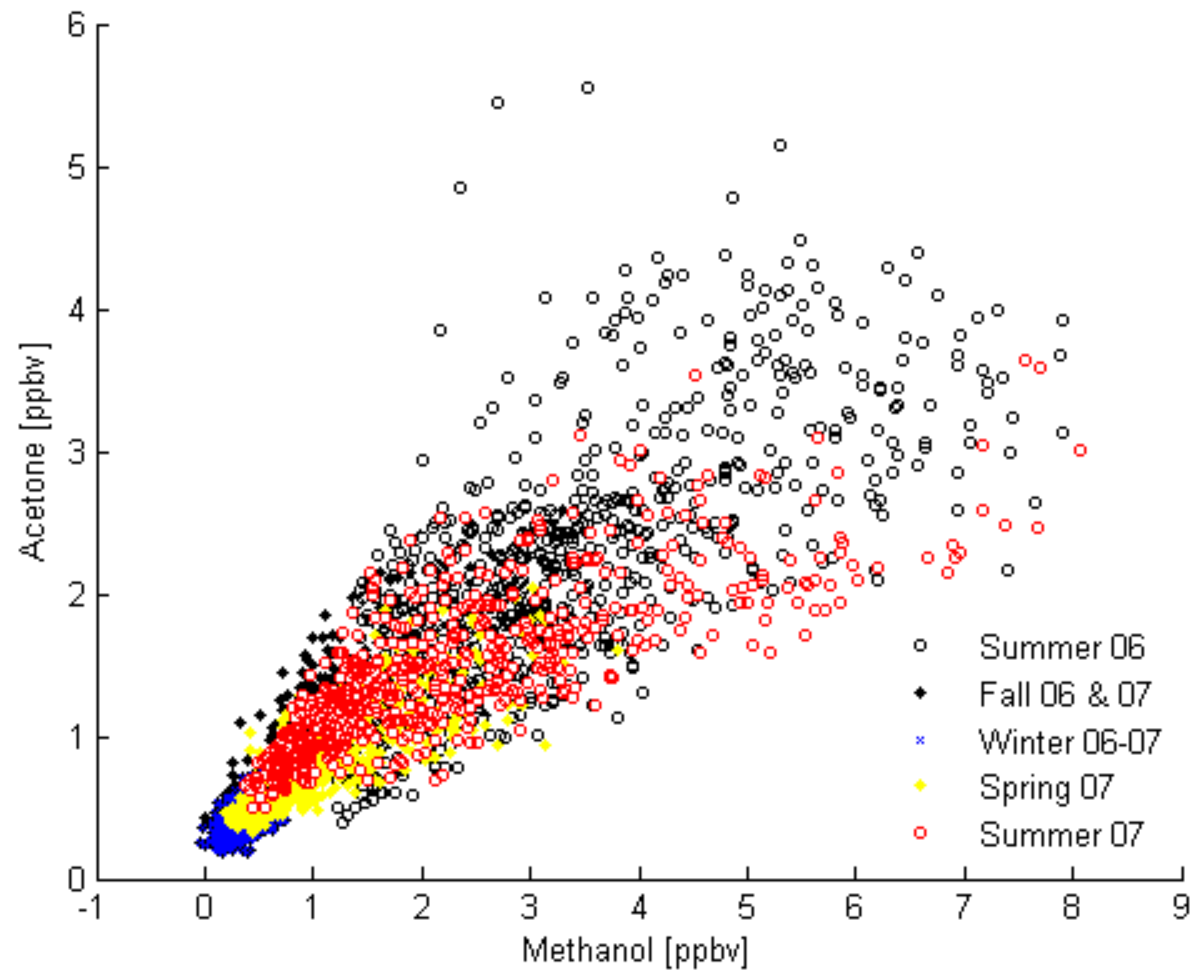

VOC concentrations: annual cycle in boreal forest

T. M. Ruuskanen et al.

Title Page

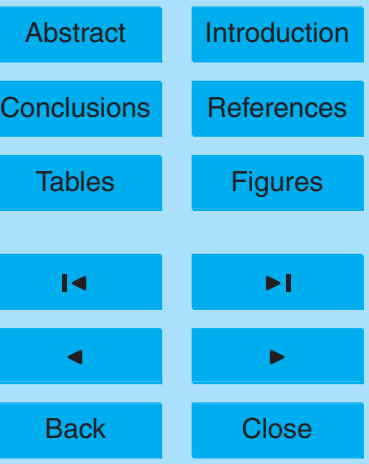

Full Screen / Esc

Fig. 6. Acetone (M59) vs. methanol (M33) volume mixing ratio measured from $14 \mathrm{~m}$ height at SMEAR II station, summer is June-August, winter December-February and spring March-May.

Printer-friendly Version

Interactive Discussion 


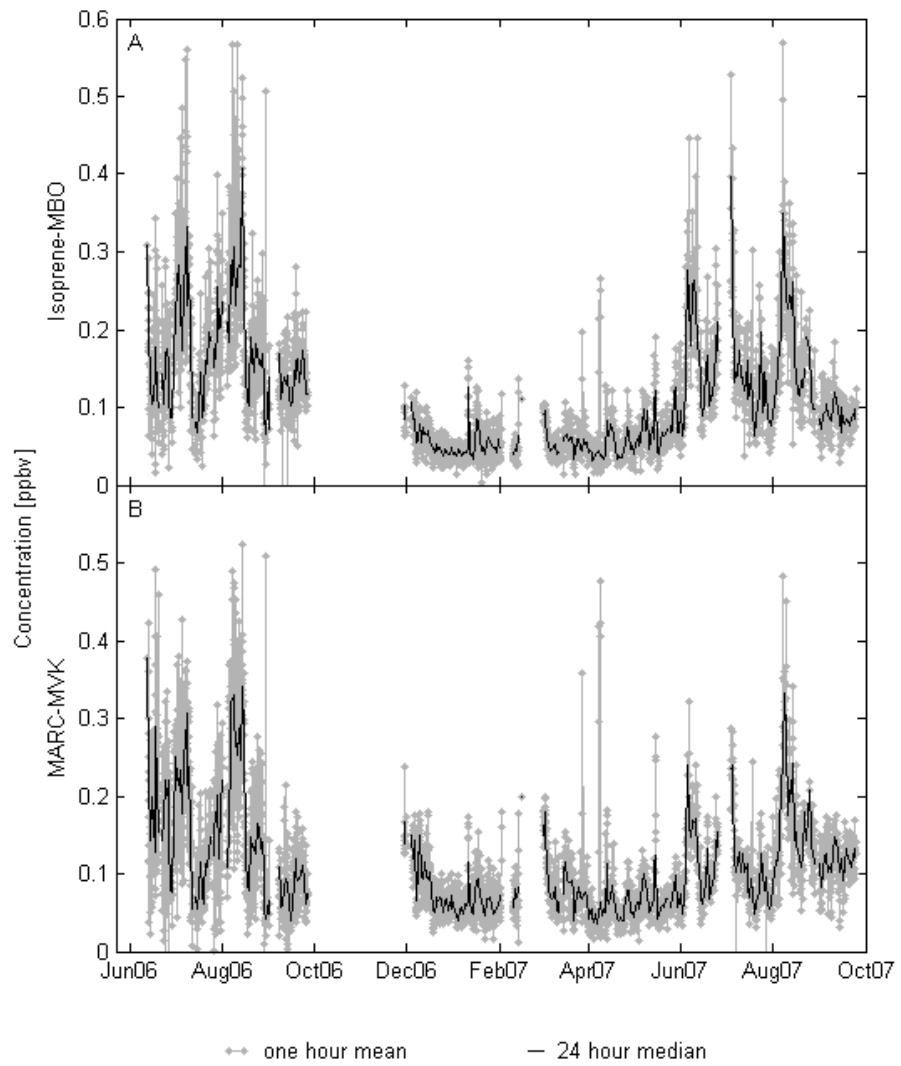

Fig. 7. Ambient isoprene-MBO (M69) and MARC-MVK (71) volume mixing ratios measured from $14 \mathrm{~m}$ height at SMEAR II station.

\section{ACPD}

9, 81-134, 2009

VOC concentrations: annual cycle in boreal forest

T. M. Ruuskanen et al.

Title Page
Abstract

Conclusions

Tables

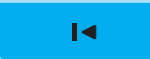

4

Back
Introduction

References

Figures

$\rightarrow$

$>$

Close
Full Screen / Esc

Printer-friendly Version

Interactive Discussion 


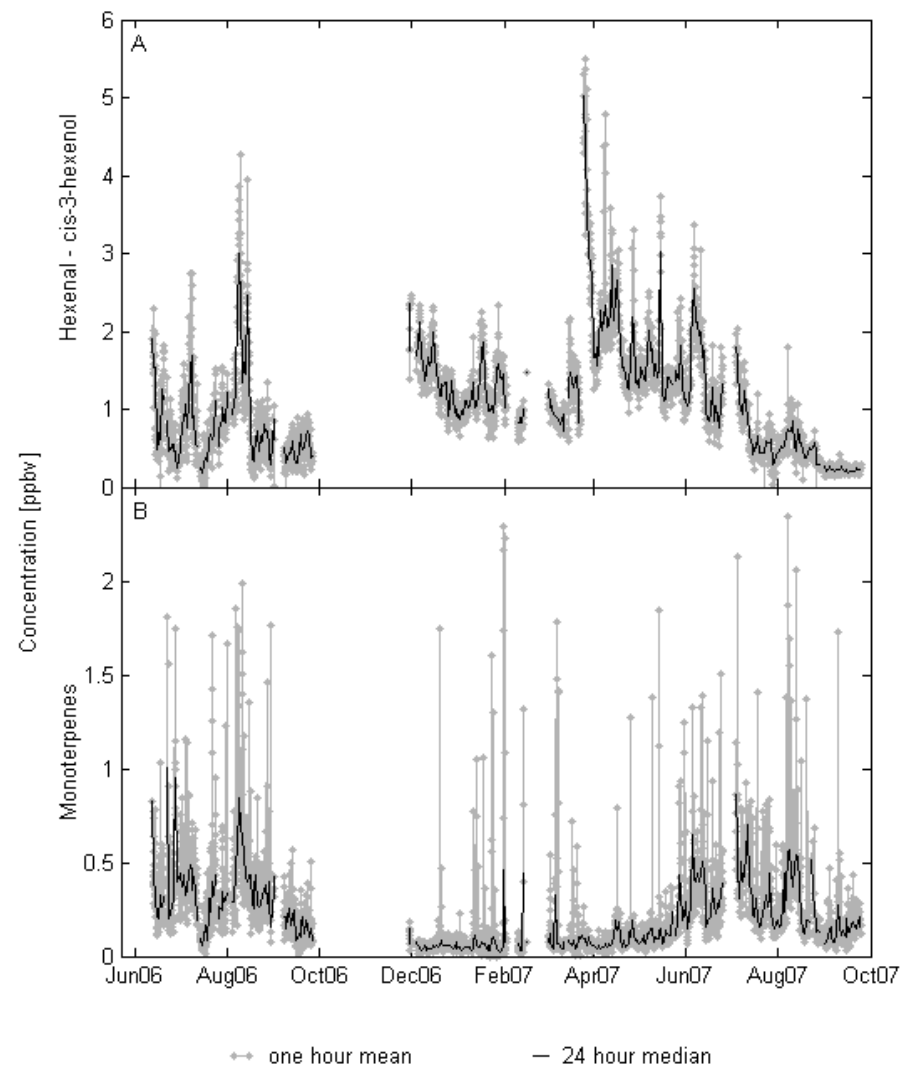

Fig. 8. Ambient hexanal - cis-3-hexenol (M101) and monoterpene (M137) volume mixing ratios measured from $14 \mathrm{~m}$ height at SMEAR II station.
ACPD

9, 81-134, 2009

VOC concentrations: annual cycle in boreal forest

T. M. Ruuskanen et al.

Title Page

Abstract

Introduction

Conclusions

References

Tables

Figures

14

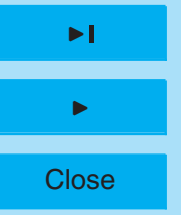

Back

Full Screen / Esc

Printer-friendly Version

Interactive Discussion 


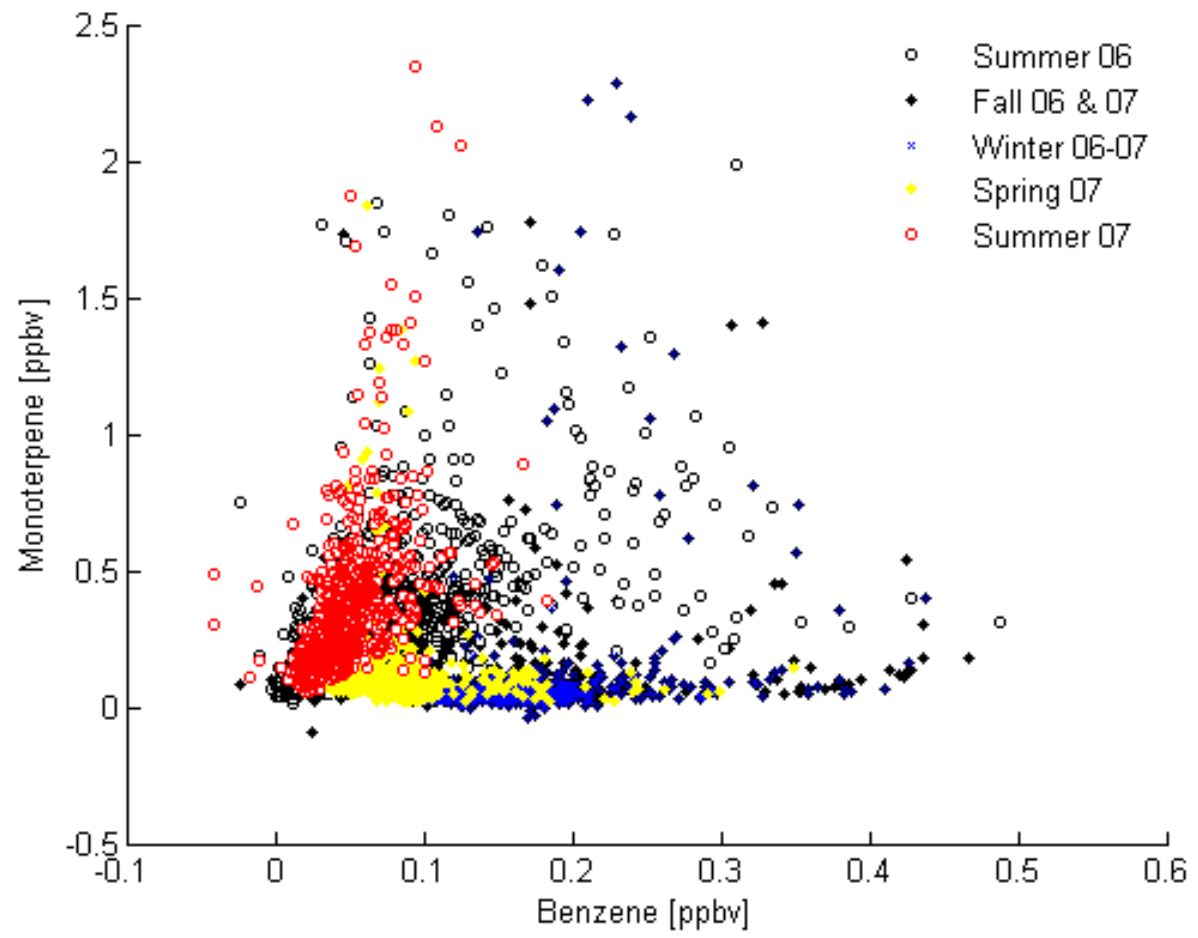

Fig. 9. Monoterpenes (M137) vs. benzene (M79) volume mixing ratio measured from $14 \mathrm{~m}$ height at SMEAR II station, summer is June-August, winter December-February and spring March-May.

\section{ACPD}

9, 81-134, 2009

VOC concentrations: annual cycle in boreal forest

T. M. Ruuskanen et al.

Title Page

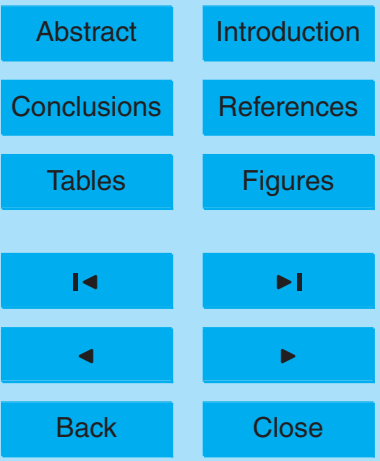

Full Screen / Esc

Printer-friendly Version

Interactive Discussion 


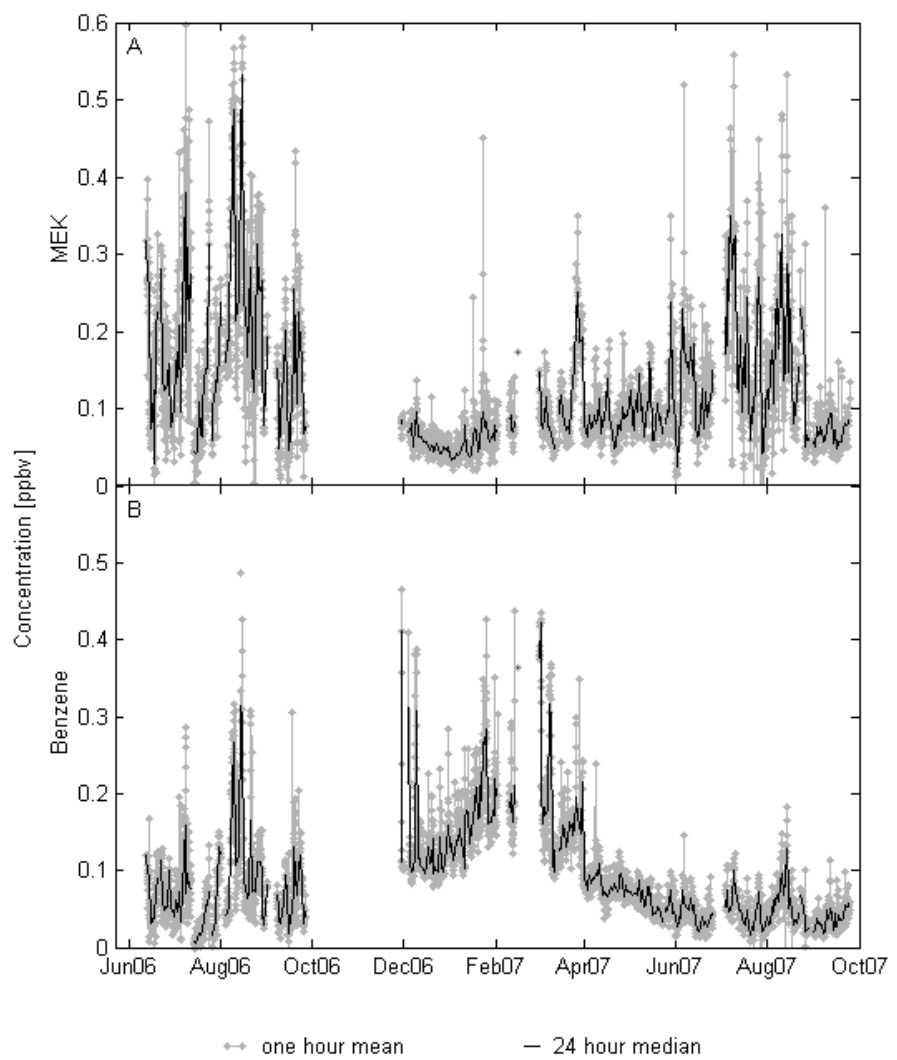

Fig. 10. Ambient MEK (M73) and benzene (M79) volume mixing ratios measured from $14 \mathrm{~m}$ height at SMEAR II station.
ACPD

9, 81-134, 2009

VOC concentrations: annual cycle in boreal forest

T. M. Ruuskanen et al.

Title Page
Abstract

Conclusions

Tables

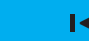

Back
$>$
Printer-friendly Version

Interactive Discussion 


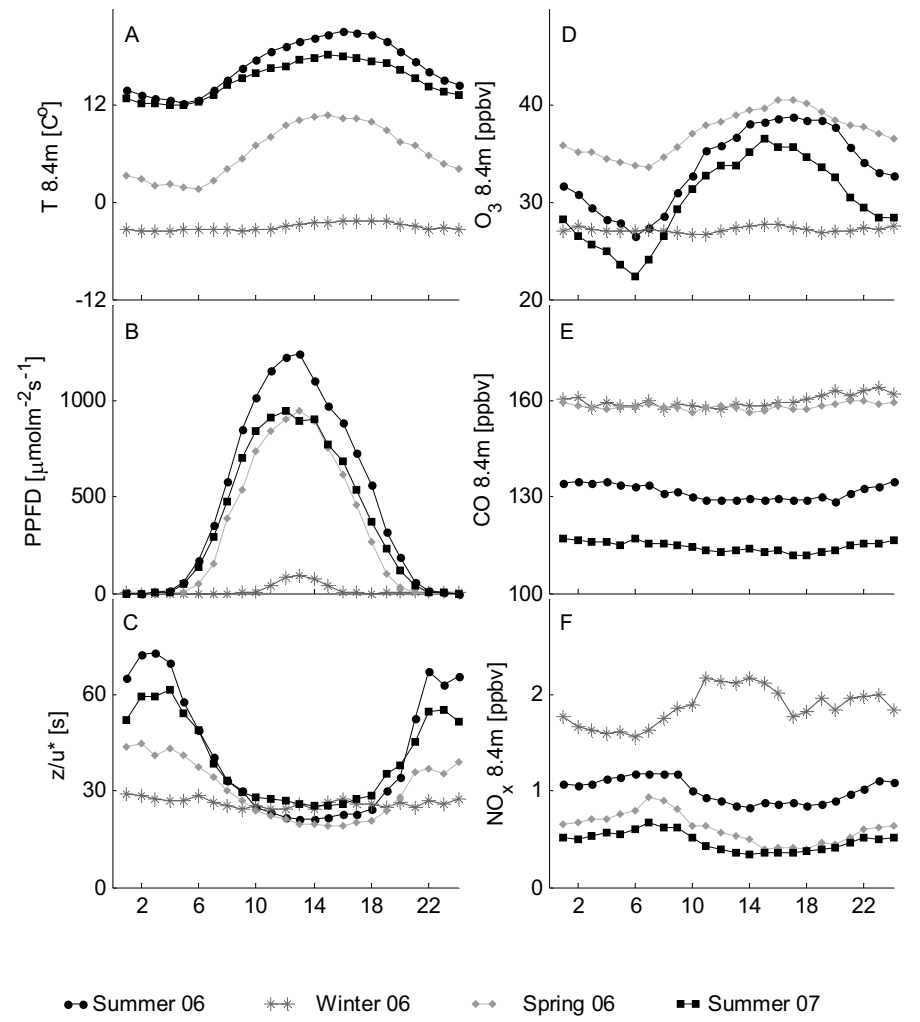

Fig. 11. Diurnal variation of temperature, ozone $\left(\mathrm{O}_{3}\right)$, carbon monoxide $(\mathrm{CO})$ and $\mathrm{NO}_{\mathrm{x}}$ were measured at $8.4 \mathrm{~m}$ height, photosynthetical photon flux density (PPFD) above canopy and turbulent mixing timescale for measurement height of $14 \mathrm{~m}\left(t=z / u^{*}\right)$ during the ambient VOC measurements. Hourly medians were calculated from half an hour averages for winter (DecemberFebruary), spring (March-May) and summer (June-August).

\section{ACPD}

9, 81-134, 2009

VOC concentrations: annual cycle in boreal forest

T. M. Ruuskanen et al.

Title Page

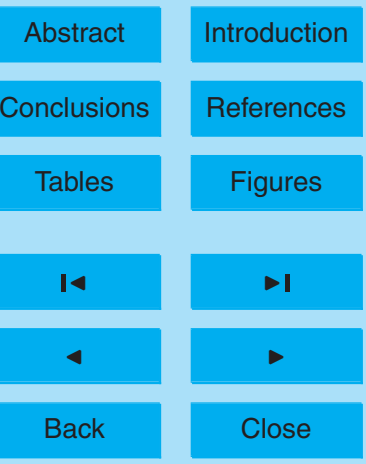

Full Screen / Esc

Printer-friendly Version

Interactive Discussion 

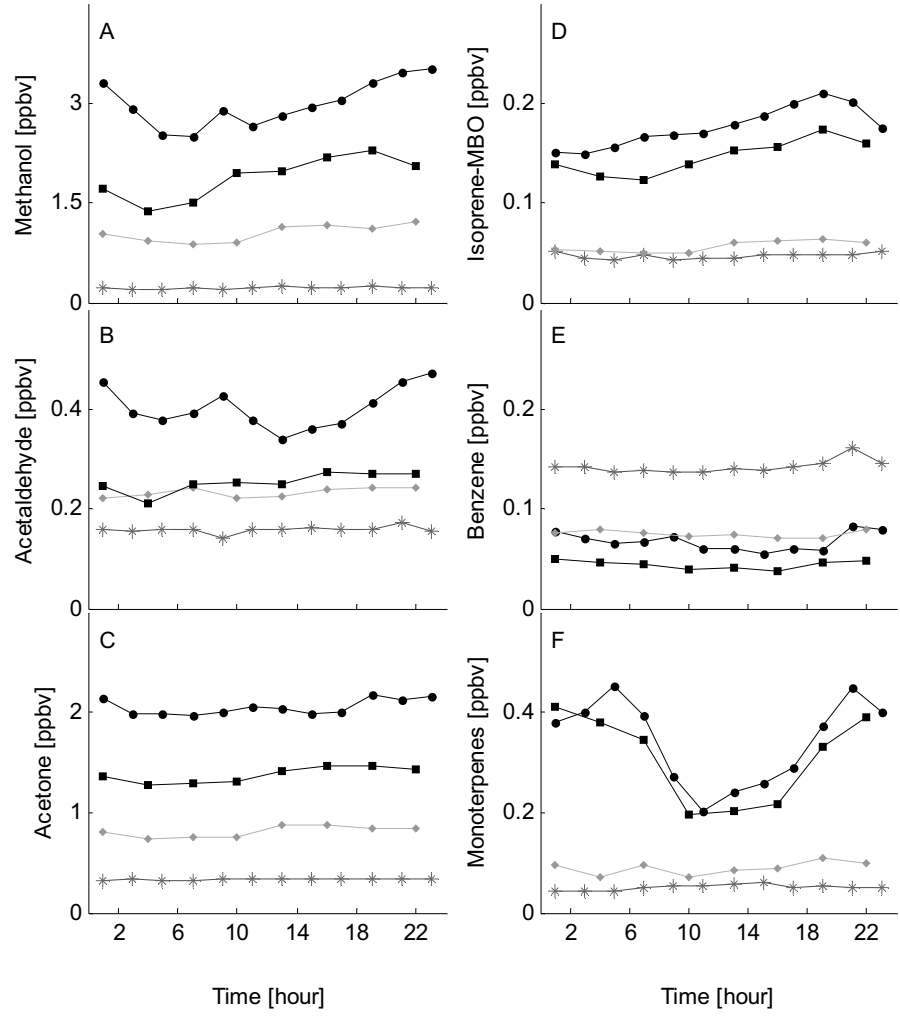

• Summer 06

* Winter 06

VOC concentrations: annual cycle in boreal forest

T. M. Ruuskanen et al.

Fig. 12. Diurnal variation of methanol (M33), acetaldehyde (M45), acetone (M59), isoprene (M69), benzene (M79) and monoterpenes (M137). Hourly medians were calculated from hourly averages for winter (December-February), spring (March-May) and summer (June-August), fall is not presented, due to instrument breakdowns from October to beginning of December 2006.

Title Page

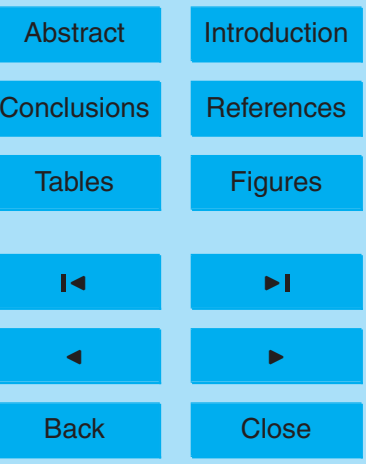

Full Screen / Esc

Printer-friendly Version

Interactive Discussion 


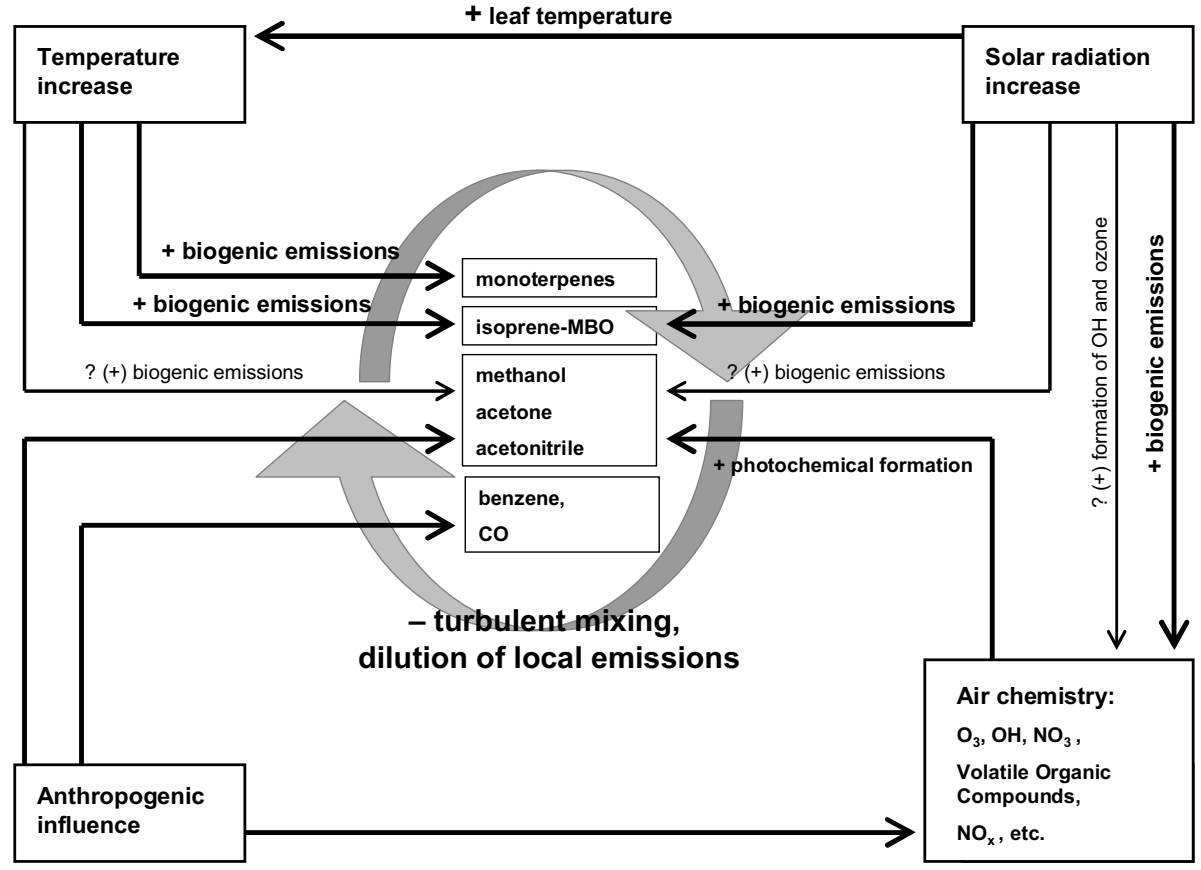

Fig. 13. Possible effects of changes in environmental parameters on volume mixing ratios based on the annual variation of summer measurements of monoterpene, isoprene-MBO, methanol, acetone, acetonitrile and benzene. Signs + and - indicate positive and negative response and (?) that the influence is uncertain. Arrows in the center portray turbulent eddies that transport compounds and dilute local emission.

\section{9, 81-134, 2009}

VOC concentrations: annual cycle in boreal forest

T. M. Ruuskanen et al.

\section{Title Page}

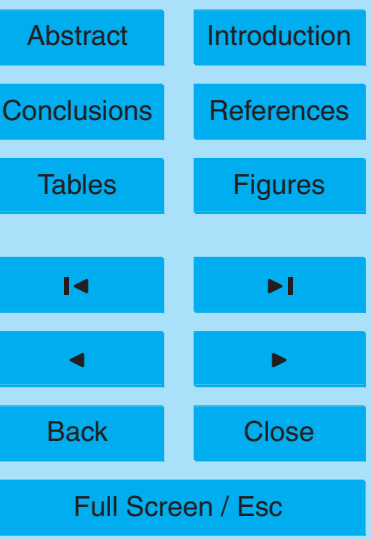

Printer-friendly Version

Interactive Discussion 